Article

\title{
The Effects of a First-Time Experience on the Evaluation of Battery Electric Vehicles by Potential Consumers
}

\author{
Felix Hinnüber ${ }^{1}$, Marek Szarucki ${ }^{2}$ (D) and Katarzyna Szopik-Depczyńska ${ }^{3, *(D)}$ \\ 1 Doctoral School, Cracow University of Economics, 31-510 Krakow, Poland; felix.hinnueber@gmx.de \\ 2 Department of Strategic Analyses, College of Management Sciences and Quality, Cracow University of \\ Economics, 31-510 Krakow, Poland; szaruckm@uek.krakow.pl \\ 3 Department of Corporate Management, Institute of Management, University of Szczecin, \\ 70-101 Szczecin, Poland \\ * Correspondence: katarzyna.szopik-depczynska@usz.edu.pl
}

Received: 18 October 2019; Accepted: 30 November 2019; Published: 9 December 2019

check for updates

\begin{abstract}
In some countries, such as Norway, there is significant growth in the proportion of battery electric vehicles (BEVs) among new registrations. This is not the case in Germany, where less than 1\% of all newly registered vehicles are electric cars. This disparity raises the questions of whether the performance factors of current BEVs (e.g., driving range) are able to compete with petrol-powered cars and how they are perceived by potential customers. Using marketing methods, car manufacturers can influence attitudes towards products and increase purchase intentions. Most prior studies used experiments in different settings to find out the perceived value of BEVs among potential customers, taking into account a longer perspective. There are no prior studies on the influence of short test drives on the value perception of BEVs. The main objective of this article was to explore and assess the effects of a first-time experience on the evaluation of BEVs by potential consumers in the German market (around the city of Münster, in the North Rhine-Westphalia region). We utilized the concept of a sensory marketing approach in the form of a short (10-15 $\mathrm{min})$ test drive experiment. The results showed that perceptions, in terms of acquisition costs and acceleration/driving pleasure in particular, are developing positively. Other increasing values are maintenance and energy costs, engine/battery reliability, range in $\mathrm{km}$, and driving comfort. In addition, the perception of all other performance factors has developed positively. Also, willingness to buy a BEV increased after the short test drive. The experiment shows that short test drives with BEVs are a suitable means to support the widespread promotion of electric cars.
\end{abstract}

Keywords: R\&D; battery electric vehicles; short test drives; first-time experience; consumer experience

\section{Introduction}

In light of environmental protection issues, there is a growing interest in reducing pollution by finding alternative ways of living. For this reason, car manufacturers are considering the long-term goal of limiting the production of traditional petroleum-driven cars and focusing on the development of electric vehicles (EVs) or battery electric vehicles (BEVs). Thus, there is a growing interest in their market potential. Many car users are aware of some benefits of using electric vehicles, although there are still many doubts about their overall value. There are many reasons for such a situation and many factors influencing the perceived value of EVs [1,2]. A better understanding of these factors will provide insights for both theorists and managers, especially marketers responsible for product development and its introduction into new markets. 
Some factors influencing customer experience and enhanced perceptions of product value are broadly discussed in the literature [3]. Most studies utilized experiments in various settings to find out the perceived value of BEVs among potential customers, taking into account a longer perspective of 3 to 12 months [4-7]. To the best of our knowledge, there are no prior studies of the effects of short test drives on BEV value perception or purchase intention.

It is of the utmost importance to attract and persuade potential customers to start using these cars by providing additional kinds of resources to customer consumption and value-generating processes. Gronroos suggests that companies should use their relations with customers to sway the value creation processes [8]. Some authors stress the importance of customer involvement in value co-creation practices [9-12] while others argue for the utilization of sensory stimulation to influence customer intentions to purchase a product [13]. This issue has been analyzed via sensory marketing [14,15], exploring the involvement and influence of different senses on customer experiences with respect to the value of a product or service. Prior studies have used stated preference information to identify preferences towards BEVs and their characteristics, with some also stressing latent attitudes that influence individual choices $[5,16]$. Stated preference information is needed when exploring new vehicles that are not widely available on the market. Nevertheless, stated preference experiments on BEVs, where potential customers articulate their attitudes without having any real experience of the product, leads to skepticism instead of an increased perception of product value, and therefore may lead to a lowered intent to purchase. According to Li et al. [17], purchase intention is very important to the popularization of BEVs and the development of the industry.

The German market for BEVs is growing, although the pace is still slow despite governmental financial support to companies and individuals who order electric cars or plug-in hybrids [18]. According to initial results, the demand for such cars is behind expectations [19]. Instead of searching for factors that hamper widespread acceptance of battery electric vehicle technology in Germany, we aimed to answer the question of how companies can influence BEVs' value perception and increase purchase intention. In order to answer this question, our study explored and assessed the effects of a first-time experience on the evaluation of BEVs by potential consumers in the German market (around the city of Münster, in the North Rhine-Westphalia region). Compared to previous studies, ours is the first to use short test drives to determine customers' BEV perception and purchase intention. Data collected from our short test-driving experiments was processed with SPSS using statistical measures.

The structure of the paper is as follows. First, we present the theoretical background related to BEV performance factors influencing customer value perception. Second, the methodology of data collection, utilizing a test-driving experiment and its processing using statistical methods, is provided. Third, we present the results and discuss the contribution of the paper together with theoretical and managerial implications, as well as the study's limitations and future research prospects.

\section{Literature Review and Hypotheses}

\subsection{Growing Importance of the BEV Market}

There is a growing debate over the potential of electric vehicles to reduce global and local emissions as well as whether they can ensure a relevant future market for car sales worldwide [20-22]. Some of the main potential advantages of the widespread use of BEVs are lower greenhouse gases and cleaner air, leading to healthier living conditions through the reduction of local $[23,24]$ : Electric engines manage to convert $95 \%$ of the used energy into power, whereas petrol engines convert just $65 \%$. Electric engines are easier to produce, but their batteries are problematic due to long charging times and a short range in $\mathrm{km}[23,25]$.

In 2012, the German government announced the goal of one million electric vehicles registered on German roads by the year of 2020. Moreover, governmental support for research and development 
should secure a leading position for the German automotive industry [26]. More than 800,000 people are employed in the field, accounting for a turnover of 407 billion EUR [27].

Electric mobility provides an opportunity to improve greenhouse emissions and protect public health by making the air cleaner [23]. In 2017, less than one percent of all newly registered cars were BEV. The majority of cars are powered by gasoline [28]. A slight rise in BEV purchases in 2017 is also connected to government subsidies introduced in 2016. Individuals and companies can get additional payments when ordering an electric car or a plug-in hybrid [29]. With 54,274 cars (hybrid and fully electric) financed since May 2015, the demand is behind expectations [28]. The monetary path towards BEV market growth is viewed negatively. For example, Dudenhöffer et al. [25] evaluated the matter of the environmental bonus and drew unfavorable conclusions with respect to the German market. Firstly, some of the money Germans spend on BEVs is not flowing into the German companies because they are buying imported cars. Secondly, the artificial price appeal can have a positive short-term effect, but after suspending the subsidies, the opposite outcome can occur, and the demand declines drastically. A better application of government funds is to encourage the development of competitive products and technologies [25].

As mentioned above, BEV registrations in Germany are lower than one percent. In Norway, a different picture can be observed. In 2017, 3 out of 10 newly registered cars were powered by electric energy only. Another $29 \%$ of the currently registered vehicles are plug-in hybrids [30]. Looking at Norway, massive support by the government can be observed [31,32]. Norway provides free parking in cities and allows the use of bus lanes for BEV drivers. People that are using BEV also do not have to pay toll charges. The most significant impact is due to the waiver of value-added tax, which means a price reduction of $25 \%$ [33]. Looking at these advantages, it becomes clear that the high registration numbers are a result of artificial benefits that are provided by the government. Germany can choose the same path; however, different possibilities should be evaluated before burdening taxpayers with such an investment. Bobeth and Matthies [34] indicate that the public debate over electric vehicles in Germany is often related to the negative factors instead of their advantages. Moreover, they refer to the fact that, through ignorance and inexperience, only a small group of innovators are using this technology in Germany. Most people are unwilling to invest in the new technology until it becomes more popular. A sufficiently large number of innovators, or early adopters, can serve as proof for the rest of the population that the technology is suitable for everyday use.

Marketing departments have the opportunity to take appropriate measures to increase the volume of BEV purchases. One promotional option is to offer potential customers an initial test drive to demonstrate the advantages of BEVs. Due to a gap in the literature on the impact of short test driving, however, the effectiveness of this approach must still be determined. Thus, our main research question was to investigate the influence of a short test-drive experience on the perceived characteristics of battery electric vehicles in the German market. To answer this question, an experiment was needed that contained a test drive with an electric car.

In the next section, the current literature is reviewed to identify positive and negative performance factors that distinguish electric-powered cars from fuel-powered cars.

\subsection{Positive Performance Factors of BEVS}

\subsubsection{Environmentally Friendly}

The discussion about ecological balance is ongoing and remains a crucial point regarding the acceptance of BEV. Consumers question the energy source of electric-powered engines. Some may not be in favor of purchasing a BEV because the energy is produced from coal mines, which are causing harm to the environment [35]. Regarding Germany, this concern seems to be valid: In 2016, only $29 \%$ of energy production came from renewable resources [36].

Ellingsen et al. [37] discovered that more greenhouse gas emissions are produced by the production of electric cars than by the production of vehicles with combustion engines. BEV production results in 
$60 \%$ more $\mathrm{CO}_{2}$ emissions, compared to the production of fuel-powered cars. The main reasons for this are the battery and other electronic components [38]. However, the emissions from BEVs during usage are relatively lower. BEVs reach a breakeven point in terms of environmental friendliness between 44,000 and 70,000 km, depending on the size and model [37]. Hence, a positive result can only be reached in the long run, by using electricity produced with low emission methods. Peng et al. [39] estimate a positive effect in the total lifecycle of a BEV that equates to up to $72 \%$ lower emissions compared to cars with combustion engines.

\subsubsection{Driving Comfort and Acceleration}

The experience of driving an electric car is unique: BEV users experience increased driving comfort due to less noise [6]. Furthermore, comfort is improved because most electric engines do not require a gearbox. Driving is smooth, without the interruption of gear changes [40]. Another positive aspect of BEVs is the acceleration, especially during lower speeds. Dynamic handling is perceived positively by BEV drivers [41].

\subsubsection{Total Cost of Ownership}

A further factor is the cost of owning of a BEV. The purchase price is only one part of the total cost of ownership (TCO), which also includes operating expenses. By using this approach, an economic judgment of electric vehicles can be made [42]. TCO includes the cost of energy, depreciation, insurance, taxes, and subsidies [43].

Potential customers estimate a higher TCO compared to fuel-powered vehicles. This assumption was examined in a study by Wu et al. [44]. The results are highly dependent on the size of the car and the distance driven per year. The purchasing cost is currently higher, and the operating cost is lower for BEVs. It can be concluded that the more kilometers driven, the more cost effective the electric vehicle will be. Consumers tend to focus only on the purchasing cost. A marketing label that provides information on savings per annual distance driven could improve perceptions of the technology. Furthermore, since lower-class vehicles are purchased for less, these can presumably offer a cost advantage faster than luxury cars [44].

As noted above, a main reason the purchasing price for BEVs is high is the battery packs. Higher ranges and more power lead to increased costs [45]. However, this increase can be seen positively [46-48]. Between 2013 and 2015, the prices for lithium-ion batteries decreased by $31 \%$, and future decreases can be expected [49].

Depending on the models, operating costs are less than 50\% compared to fuel-powered cars [50]. Lower fixed and variable costs are connected to BMVs' lower service and maintenance requirements, mainly because of the simpler electric engine [43]. Moreover, no taxes have to be paid, unlike with conventional vehicles [51].

\subsection{Negative Performance Factors}

\subsubsection{Range}

Range is defined as the distance a vehicle can drive without recharging. This performance factor is crucial, because cars powered solely by electricity currently cannot provide a range equal to that of fuel-powered cars. In addition, recharging takes more time than refilling a car with gasoline. In consequence, the consumer has less flexibility [35].

There are several aspects affecting a vehicle's range. The weight of the vehicle influences the efficiency of the car. Therefore, if a battery has a bigger capacity, the range is extended, but the effectiveness goes down. Another critical factor is driving style. Most BEVs' recharge their batteries when slowly braking, using regeneration [52]. Consequently, a smooth driving style, including moderate acceleration, is most favorable. Moreover, speed has a significant impact. High speeds are less efficient. For example, traveling at 120 instead of $70 \mathrm{~km} / \mathrm{h}$ reduces the range by more than $50 \%$ [53]. 
Heating systems are another crucial point, especially in winter. A car with a combustion engine uses the heat of the powertrain, whereas a BEV requires a process to produce heat, which can reduce the potential distance up to $30 \%$ [54].

Fetene et al. [55] conducted an experiment using big data from BEVs. They revealed a discrepancy between the range mentioned by the car brands and the actual range reached in a normal consumer environment. The range stated by the manufacturers could be reached at $14{ }^{\circ} \mathrm{C}$ and a constant speed at $52 \mathrm{~km} / \mathrm{h}$. These values seem to be unrealistic and also depend on the weather conditions, patterns of driving, and other environmental factors. Modifications within the testing procedures are recommended, including realistic driving experiments by authorities [55].

\subsubsection{Infrastructure and Charging}

Another essential factor is the charging possibilities, which can provide flexibility and comfort [23]. According to the information provided by the manufacturer, the Volkswagen Golf-E requires a charging time of $17 \mathrm{~h}$ at a standard socket, whereas the charging time is estimated at $5 \mathrm{~h}$ and $20 \mathrm{~min}$ using their wallbox. If a customer has the opportunity to connect to a DC charger, $80 \%$ of the battery volume can be reached within $45 \mathrm{~min}$ [56]. Charging times between 5 and $17 \mathrm{~h}$ could be a hindrance, though it is worth noting that most electric cars are charged overnight [57].

The number of charging locations in Germany must be increased [53]. Infrastructure is not only defined as places to charge but also by the way these points are arranged [58]. Bonges and Lusk argue that they should be equipped with four ports, serving four parking spaces, to maximize efficiency [59].

A lack of standardization is also a problem [23]. Ko and Hahn [60] suggest using a battery swap mechanism that eliminates problems like lengthy charging and other negative aspects connected to recharging.

\subsubsection{Top Speed, Durability, and Security}

Various performance and safety factors influence the acceptance of BEVs. For most electric vehicles, the top speed is between 120 and $160 \mathrm{~km} / \mathrm{h}$. Without this limitation, the range would decrease rapidly, because of high energy consumption at higher speeds [61]. In most countries, this factor is negligible, because maximum speeds on highways are limited. In Germany, however, this is not the case: Car drivers are allowed to drive as fast as they want in some areas. As a result, speed limitation can be a hindrance for some potential customers.

Durability is another important factor. One battery pack can survive a driving distance of $120,000 \mathrm{~km}$ or more. Assuming a car is driven 14,000 km annually, this capacity would be enough for more than eight years [62].

There are two security issues that must also be mentioned. Firstly, a noiseless ride can cause safety problems. If other road users cannot hear a car, they may collide with it. Indeed, studies show an increased risk of accidents [63]. Some producers offer an artificial sound feature to solve the problem. Secondly, there is the risk of battery failure in vehicle crashes: High voltage can be a safety hazard if the integrity of a battery cell is compromised [64].

\subsection{BEV User Model}

As can be seen, there are advantages and disadvantages to the current BEV technology. Environmental-friendliness, driving comfort, total cost of ownership, acceleration, and driving pleasure are perceived as positive factors while security, durability, top speed, charging infrastructure, and charging times tend to be negative factors, when compared to gasoline-powered cars.

Several studies connected to the topic of electric mobility focus on hybrid vehicles. Their results were not incorporated in the present study. Based on our review of the literature, we developed a BEV consumer model (Figure 1). The illustration gives an overview of the factors that influence the adaptation towards electric cars. A more detailed description of the components is provided below. 


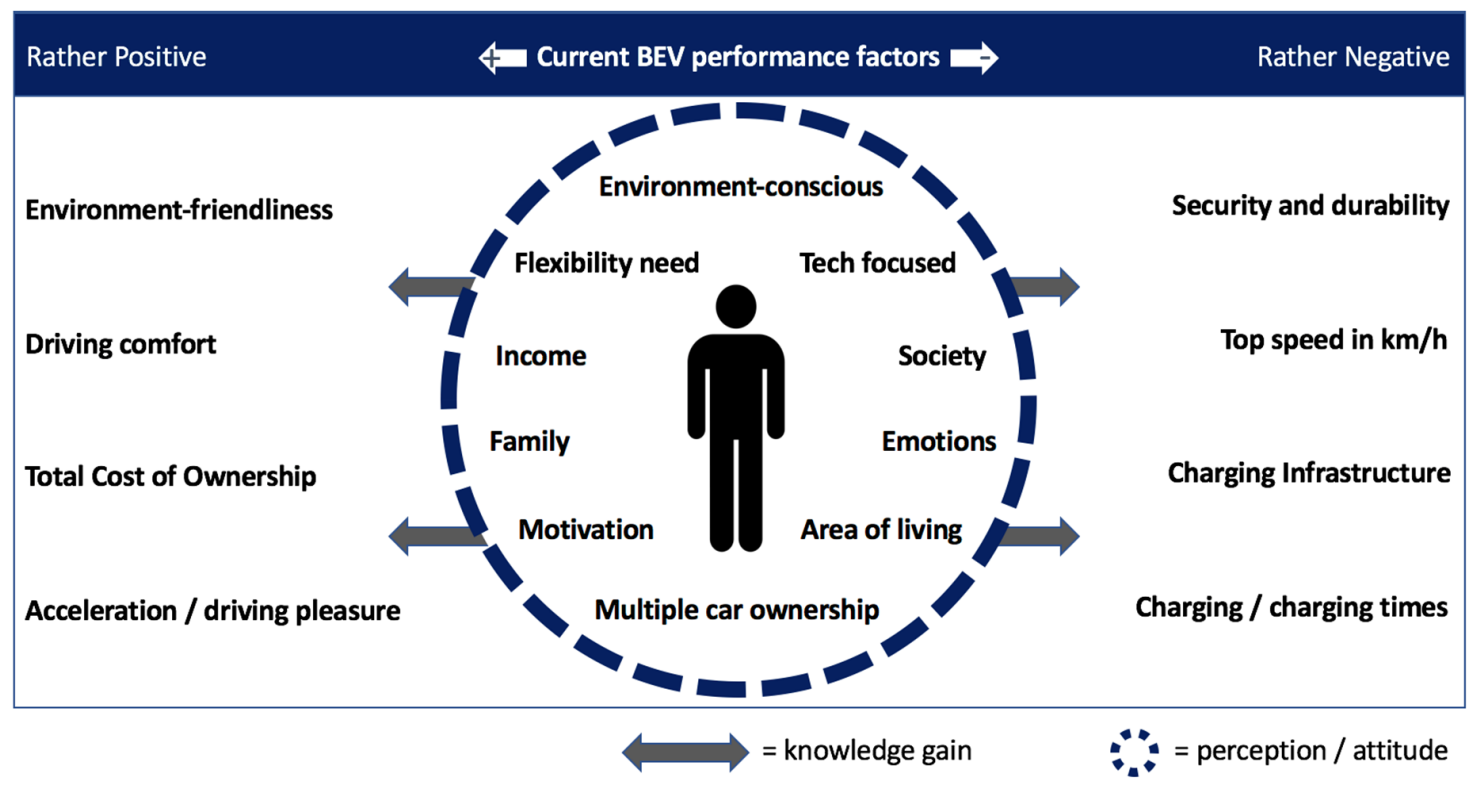

Figure 1. BEV consumer behavior model.

The widespread acceptance of BEVs is dependent on the performance of the vehicles that are offered on the market. If one considers the current state of the technology, various characteristics (performance factors) of BEVs can be classified as positive or negative, as compared to conventional vehicles equipped with an internal combustion engine. For example, the limited range can be classified as negative. If specific characteristics are favorable, the widespread acceptance of this technology will be faster. If features are rather negative, they can also be called hindrance factors, as they impede growth.

Potential users of electric cars have a certain perception of BEVs and their performance characteristics. This attitude is a key factor. An attitude is a learned tendency to react to an object or situation positively or negatively, which means that in similar situations, a person behaves the same way. Attitudes are based on previous experiences and processed information [65].

There is a direct link between attitude and purchasing behavior, but certain disruptive factors can weaken the correlation. This may occur when there is a positive attitude towards more than one product or because of situational factors, such as the appearance of promotions. Other factors that can weaken the correlation are limited financial resources and social norms; for example, a person might not buy a sports car because of adverse social reactions [66].

Knowledge can be described as the sum of information that can be recalled from memory in different situations. Consumer knowledge is information that is connected to the consumption or purchase of products. It includes familiarity with products and brands, purchase information (e.g., where to buy), and knowhow about product characteristics and usage [67]. One way to gain knowledge about electric cars is through test drives.

Personal factors, both internal and external (e.g., income), can influence attitude changes towards BEVs. Some, though perhaps not all, influencing factors are explained below.

A study conducted in Norway that compared BEV owners with conventional car owners found differences between the two subgroups. Regarding socio-demographics, electric car owners have a higher income and are younger. Additionally, households using BEV technology have more children [68]. Similarly, Nayum et al. state that high education has a positive influence on BEV adaptation. The same holds for a high income [69].

In contrast, Hidrue et al. (2011) claim that annual income is not a crucial factor. Additionally, they reveal that multiple car ownership is not of importance [70]. Karlsson disagrees, arguing that due to the limited range of electric vehicles, households with more than one car are more likely to be potential consumers because they can have the flexibility of choosing between a long-range combustion engine car and an electric vehicle [71]. Plötz et al. identifed the profile of early users of this technology. 
According to their results, the potential targets are middle-aged men living in rural areas with their families; they own more than one vehicle and, due to their higher income, can afford a BEV [20].

The scientific literature presents influential variables that include psychological and societal acceptance of the technology. Moons and de Pelsmacker show that positive emotions, resulting, for example, from the awareness of using an environmentally friendly car, have a positive effect on the willingness to adapt to this technology. Negative emotions can have adverse effects [72].

Beside positive emotions, the $\mathrm{BEV}$, as a symbol for green consumer behavior, can have an impact. Castaneda et al. [73] carried out a study with several interesting findings. Social groups can influence ecological behavior by putting pressure on individuals. Social norms are defined in these clusters, and people who are not following their unwritten rules are punished by society. Since electric vehicle users are still a minority, the social pressure on drivers of conventional vehicles is not that strong. Nevertheless, the BEV can function as a symbol to display social status or a unique identity [17]. People showing an environmentally conscious self-identity have a high potential to adapt to BEV. This behavior is also connected to worries about climate change [74]. Environmental awareness has led to a growing importance of green consumer behavior. Marketing departments have to consider this circumstance [75]. Conversely, Prothero et al. [76] discuss an observable gap between attitudes toward sustainability and actual behavior. A United Nations survey shows this paradox: In total, $40 \%$ of consumers could imagine buying green products, but only $4 \%$ demonstrate this attitude with action [77]. Despite these observations, Axsen et al. demonstrate that consumers who follow a green and technology-oriented lifestyle are more motivated to use electric vehicles [40].

Environmentally aware consumers have an important reason to buy cars that are powered by electric engines. Driving this kind of vehicle reflects their desire to protect the environment. Consumers make their purchase decision with the intention to do something good for society and to weaken the power of the oil industry. Moreover, they are presenting their individuality. In the early stages of technological development, they can show that they are first taking on the role of an innovator [78].

Degirmenci and Breitner measured the importance of environmental performance compared to the price and range of electric vehicles and found that eco-friendliness is weighted with a higher priority [79]. Hence, it may be assumed that people will accept a higher price or a lower range if they can contribute to the protection of the environment. Yet, van Rijnsoever et al. found a gap between attitudes toward environmentally friendly cars and people's actual behavior [80].

It is important to stress that models of customer experience and customer experience management are gaining more and more attention in marketing publications, stressing the concept of sensory or multi-sensory marketing [14,15,81,82]. According to Krishna sensory marketing engages consumers' senses and influences their perception, evaluation, and behavior, usually aiming to increase their purchase intention [14]. Marketing methods in this context describe approaches that are connected to experience with a product or brand [83]. Pine, Pine, and Gilmore stress the importance of the customer in comprehending what an experience means to him or her [84]. It usually happens when a company purposefully creates an experience with the goal of involving customers. This happens when companies provide consumption experiences, communication, and contacts that build an experience in their minds $[85,86]$ In order to strengthen customer experience and brand awareness, it is best to involve as many senses as possible. According to Hultén [15], in addition to vision, other senses, such as smell, sound, taste, and touch, may "reinforce a positive feeling, following the experiential logic, that generates a certain value to the individual and, in particular, creates a brand image". The involvement of more senses leads to a more comprehensive experience of the product or service. Such a multi-sensory experience is more engaging and more memorable than other forms of education [87]. Muhammad and Artanti investigated whether an experience can have a positive effect on consumer satisfaction as well as on word of mouth [88]. In particular, approaches that target experiences are becoming more and more relevant due to the perceived exchangeability of brands [89].

Mooy and Robben distinguish between indirect and direct experience. The most indirect form is a product description, which is followed by word of mouth and a product photo that, for example, 
can be displayed in a printed advertisement [90]. A product that can be seen in a shopping window is closer to direct experience, as is a product demonstration. Finally, the authors describe hands-on experience as pure, direct experience. Mooy and Robben (2002) agree that direct experience improves the ability to process information [90]. A product can be used as a communication tool that supports decision making during the purchasing process. Therefore, by applying a multi-sensory marketing perspective, companies can utilize sensorial strategies conveyed "through sensors, sensations and sensory expressions in relation to the five human senses in leaving imprints of a good or service" [81].

\subsection{The Impact of Experience with BEV}

Various authors have investigated the impact of experience on the perceived characteristics of BEVs. The main findings of their studies, with their time/length of experiment and number of participants, are displayed in Table 1.

Table 1. BEV experience and its influence.

\begin{tabular}{|c|c|c|c|}
\hline Authors & Time or Length & $\begin{array}{l}\text { Place/No. of } \\
\text { Participants }\end{array}$ & Main Findings \\
\hline $\begin{array}{l}\text { Skippon, Garwood (2011) } \\
\text { [91] }\end{array}$ & 10 miles & $\begin{array}{l}\text { UK } \\
58\end{array}$ & $\begin{array}{l}\text { - } \quad \text { mixed results after the experience } \\
\text { - } 240 \mathrm{~km} \text { are enough to consider a BEV as a } \\
\text { primary car }\end{array}$ \\
\hline $\begin{array}{l}\text { Burgess, King, Harris, } \\
\text { Lewis (2013) [4] }\end{array}$ & 6-12 months & $\begin{array}{l}\text { UK } \\
55\end{array}$ & $\begin{array}{l}\text { - } \\
\text { terformance evaluated better after the } \\
\text { change from negative to positive BEV } \\
\text { stereotype is possible }\end{array}$ \\
\hline $\begin{array}{l}\text { Jensen, Cherchi, Mabit } \\
\text { (2013) [5] }\end{array}$ & 3 months & $\begin{array}{l}\text { Denmark } \\
\quad 369\end{array}$ & $\begin{array}{l}\text { - } \quad \text { experience has a significant impact } \\
\text { on preferences } \\
\text { - } \quad \text { importance of range increased after usage } \\
\text { - } \quad \text { the marginal utility of top speed increased }\end{array}$ \\
\hline $\begin{array}{l}\text { Bühler, Cocron, } \\
\text { Neumann, Franke, } \\
\text { Krems (2014) [92] }\end{array}$ & 3-6 months & $\begin{array}{l}\text { Germany } \\
\quad 79\end{array}$ & $\begin{array}{ll}\text { - } & \text { improved overall perception } \\
\text { - } & \text { particular increase in perceptions of } \\
\text { - } & \text { refueling costs and driving pleasure } \\
\text { no change in purchase intention }\end{array}$ \\
\hline $\begin{array}{l}\text { Schneider, Dütschke and } \\
\text { Peters (2014) [7] }\end{array}$ & $\begin{array}{l}\text { Few weeks until six } \\
\text { months }\end{array}$ & $\begin{array}{l}\text { Germany } \\
\quad 145\end{array}$ & $\begin{array}{l}\text { - Positive change regarding driving pleasure, } \\
\text { acceleration and reaction of others } \\
\text { - Negative change regarding availability of } \\
\text { public charging stations }\end{array}$ \\
\hline $\begin{array}{l}\text { Rauh, Franke, Krems } \\
\text { (2015) [93] }\end{array}$ & $27.8 \mathrm{~km}$ & $\begin{array}{l}\text { Germany } \\
24\end{array}$ & - Range anxiety is reduced by BEV experience \\
\hline $\begin{array}{l}\text { Skippon, Kinnear, Lloyd, } \\
\text { Stannard (2016) [94] }\end{array}$ & $36 \mathrm{~h}$ & $\begin{array}{l}\text { UK } \\
393\end{array}$ & $\begin{array}{l}\text { - Product trial decreases willingness } \\
\text { to purchase }\end{array}$ \\
\hline $\begin{array}{l}\text { Schmalfuß, Mühl, Krems } \\
\text { (2017) [95] }\end{array}$ & $24 \mathrm{~h}$ & $\begin{array}{l}\text { Germany } \\
\quad 30\end{array}$ & $\begin{array}{l}\text { - } \quad \text { positive view of electric vehicles after } \\
\text { short-term experience } \\
\text { - no change in purchase intention }\end{array}$ \\
\hline $\begin{array}{l}\text { Rauh, Franke, Krems } \\
\text { (2017) [45] }\end{array}$ & $94 \mathrm{~km}$ & $\begin{array}{l}\text { Germany } \\
\quad 74\end{array}$ & $\begin{array}{l}\text { - Critical range experience in a protected } \\
\text { environment reduces stress in } \\
\text { future situations }\end{array}$ \\
\hline
\end{tabular}

Source: elaboration based on sources included in the table.

Reviewing the obtained results, it can be noticed that the experience of using BEVs does impact the perception of their characteristics. For example, two performance factors, acceleration and driving experience, are perceived better. The observed range and the charging issues are similar after the test drive or perceived slightly more negatively. None of the studies we found showed an increase in willingness to purchase. In spite of some negative effects, most authors recommend direct experience to increase the acceptance of BEVs. It is also worth noting that the technology is developing rapidly: From today's viewpoint, the technology in some of the cars used in past studies is outdated. 
The methods of carrying out the experiments show that in most studies, the test drive period was extensive. Some results contain a low number of participants or were not conducted in the German market. Moreover, the results of the studies often do not describe the influence of experience on the perception of single characteristics of electric cars. After studying these results, a research gap was conceptualized as the central research question of our study: What is the influence of a short test drive experience on the perceived characteristics of battery electric vehicles in the German market? Due to high costs, there seems to be no sense in producers providing electric cars for extended test periods. That is why our research investigated the impact of a short driving experience (10 min). Based on our theoretical analysis, we proposed two hypotheses ( $\mathrm{H} 1$ and $\mathrm{H} 2)$ to be tested with the help of an experiment. One is connected to the overall perception of BEVs, and the other is linked to the intention to buy a BEV:

Hypotheses 1 (H1). A short test drive experience with a BEV increases the positive attitude towards electric cars.

Hypotheses 1 (H2). A short test drive experience with a BEV increases the purchase intent towards electric cars.

The first hypothesis can be specified when, after receiving an explanation of BEV performance factors, subjects are asked to evaluate them positively or negatively. The assumption is that the test drive experience increases the perception of every single factor. Regarding the second hypothesis, if BEV characteristics are evaluated better during the test drive, it can be assumed that the purchase intent also rises.

\section{Research Methodology}

\subsection{General Description and Questionnaires}

To test the formulated hypotheses, a short test drive experiment was used to collect data from individuals using BEVs. Furthermore, the obtained results were processed with SPSS using statistical measures. Participants could rate factors influencing the perception of BEVs before and after the test drive. Moreover, this research indicates whether BEVs are able to compete with gasoline-powered cars. The test drive experiment was supported by Volkswagen AG, who provided four electric cars. The BEV's were available on six days (16-21 March 2018) for the execution of the experiment. They included one Volkswagen E-UP!, with a range of $160 \mathrm{~km}$, and three Volkswagen E-Golfs, with a range of $300 \mathrm{~km}$. A total of 20 instructors were involved. The field study was organized into four steps (Figure 2).

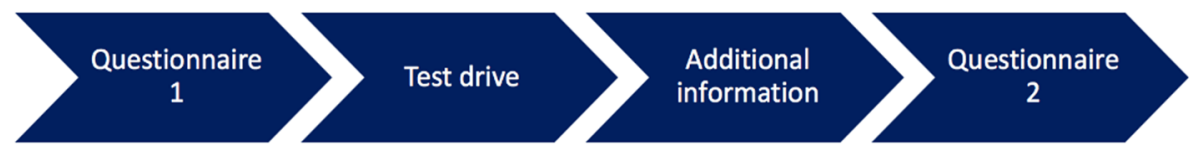

Figure 2. Steps of the field study. Source: Own study.

Before the experiment, the participants were informed that they would drive a BEV. The candidates completed the first questionnaire. They received no further facts about the vehicle or electromobility. The questionnaire was completed in the test car.

Questionnaire one was followed by the test drive phase. First, the signatures of the participants had to be obtained to ensure insurance coverage. After a short briefing by the instructor, the test drive could begin. Each test drive took about $10 \mathrm{~min}$, without an exact route.

The third phase involved additional information. This approach was chosen to simulate a test drive situation, which could also be applied by companies. The information presented in the brochure contained facts about the vehicle itself (range in $\mathrm{km}$, top speed, battery guarantee, acceleration, charging times, price comparison to cars with combustion engines, total cost of ownership, and $\mathrm{CO}_{2}$ emissions) and about electromobility in general (sustainability, charging stations that are available in Germany). 
After the test drive and perusal of the brochure, the participants completed questionnaire two, which mainly contained the same questions as in questionnaire one.

\subsection{The Questionnaires}

All questions asked the participants to evaluate a characteristic of electromobility or a particular BEV using a scale from 1 to 10 . One is synonymous with very bad, whereas 10 is synonymous with very good. At this point, a conscious decision was made against using the usual Likert scale, which contains five steps [96]. A 10-stage evaluation system was selected because it allows identification of smaller changes (e.g., from 7 to 8 ).

Participants evaluated their general attitude towards BEVs and their performance factors before and after the test drive. Moreover, test drivers rated their purchase intention on a scale from 1 to 10 , where they assessed how likely it is that they would consider an electric one when buying their next car.

One question investigated previous test drive experience with electric vehicles. Since the study aimed to evaluate the impact of first-time experience with this technology, candidates who already had experience with BEV or hybrid vehicles were excluded. The following descriptive and inductive evaluations were created with the statistical program package SPSS Statistics 25.0.

\subsection{Profile of the Participants}

It must be mentioned that all respondents taking part in the experiment were from the area around the city of Münster, in the North Rhine-Westphalia region. The results show that 131 persons completed the test drive and filled out the questionnaires. Nevertheless, 10 results were not taken into consideration due to prior experience with electric vehicles, and another 7 test drive results were disregarded because participants only answered the one questionnaire before the test drive. In total, 114 valid test drive experiments were successfully executed, and their profile characteristics are provided in Table 2.

Table 2. Profile characteristics of the participants.

\begin{tabular}{|c|c|c|c|c|c|}
\hline & Variable & Frequency & Percent & Valid Percent & Cumulative Percent \\
\hline \multicolumn{6}{|c|}{ Gender } \\
\hline \multirow{3}{*}{ Valid } & male & 62 & 54.4 & 54.4 & 54.4 \\
\hline & female & 52 & 45.6 & 45.6 & 100.0 \\
\hline & Total & 114 & 100.0 & 100.0 & \\
\hline \multicolumn{6}{|c|}{ Age } \\
\hline \multirow{5}{*}{ Valid } & $18-29$ & 46 & 40.4 & 40.4 & 40.4 \\
\hline & $30-44$ & 27 & 23.7 & 23.7 & 64.0 \\
\hline & $45-60$ & 25 & 21.9 & 21.9 & 86.0 \\
\hline & $>60$ & 16 & 14.0 & 14.0 & 100.0 \\
\hline & Total & 114 & 100.0 & 100.0 & \\
\hline \multicolumn{6}{|c|}{ Education Level } \\
\hline \multirow{7}{*}{ Valid } & Primary School & 9 & 7.9 & 7.9 & 7.9 \\
\hline & Secondary School & 23 & 20.2 & 20.2 & 28.1 \\
\hline & High School & 41 & 36.0 & 36.0 & 64.0 \\
\hline & Bachelor & 20 & 17.5 & 17.5 & 81.6 \\
\hline & Master & 18 & 15.8 & 15.8 & 97.4 \\
\hline & $\mathrm{PhD}$ & 3 & 2.6 & 2.6 & 100.0 \\
\hline & Total & 114 & 100.0 & 100.0 & \\
\hline
\end{tabular}


Table 2. Cont.

\begin{tabular}{|c|c|c|c|c|c|}
\hline & Variable & Frequency & Percent & Valid Percent & Cumulative Percent \\
\hline \multicolumn{6}{|c|}{ Estimated Income } \\
\hline \multirow{3}{*}{ Valid } & higher than average & 41 & 36.0 & 42.7 & 42.7 \\
\hline & average & 46 & 40.4 & 47.9 & 90.6 \\
\hline & lower than average & 9 & 7.9 & 9.4 & 100.0 \\
\hline \multirow{3}{*}{ Missing } & Total & 96 & 84.2 & 100.0 & \\
\hline & 4 & 18 & 15.8 & & \\
\hline & Total & 114 & 100.0 & & \\
\hline \multicolumn{6}{|c|}{ Number of Cars within the Household } \\
\hline \multirow{4}{*}{ Valid } & 1 & 32 & 28.1 & 28.1 & 28.1 \\
\hline & 2 & 65 & 57.0 & 57.0 & 85.1 \\
\hline & 3 & 17 & 14.9 & 14.9 & 100.0 \\
\hline & Total & 114 & 100.0 & 100.0 & \\
\hline
\end{tabular}

Source: Own study $(\mathrm{n}=114)$.

According to the survey, $54.4 \%$ of the participants were male and $45.6 \%$ were female. In addition, most of the respondents (40.4\%) were young people between 18 and 30 . The two second largest age groups were people aged 31 to 45 and 46 to 60 , with $23.7 \%$ and $21.9 \%$, respectively. In total, $14 \%$ of the participants were 61 or older. The group aged over 61 years was the smallest, with only $14.3 \%$. Regarding education level, high school graduates were the biggest group, with $36 \%$. Moreover, the majority of test drivers (57\%) were employed. Income was regarded subjectively, with $47.9 \%$ respondents estimating their income as average while $42.7 \%$ declared that they earn more than average. Most respondents (57\%) had two cars in their households.

\section{Results}

The data included in Table 3 displays the changes in respondents' perceptions of various factors before and after the test drive.

Table 3. Evaluation factors before and after the test drive.

\begin{tabular}{|c|c|c|c|c|c|}
\hline \multicolumn{6}{|c|}{ Group Statistics } \\
\hline Variable & Time & $\mathbf{N}$ & Mean & Std. Deviation & Std. Error Mean \\
\hline \multirow{2}{*}{$\begin{array}{c}\text { General attitude toward } \\
\text { electric cars }\end{array}$} & before test drive & 114 & 6.86 & 2.073 & 0.194 \\
\hline & after test drive & 114 & 7.62 & 1.767 & 0.165 \\
\hline \multirow{2}{*}{$\begin{array}{l}\text { knowledge about electric } \\
\text { cars }\end{array}$} & before test drive & 114 & 4.18 & 2.066 & 0.194 \\
\hline & after test drive & 114 & 5.89 & 1.918 & 0.180 \\
\hline \multirow{2}{*}{$\begin{array}{l}\text { willingness to purchase } \\
\text { an electric car }\end{array}$} & before test drive & 114 & 3.79 & 2.302 & 0.216 \\
\hline & after test drive & 114 & 5.35 & 2.417 & 0.226 \\
\hline \multirow{2}{*}{ estimation of price } & before test drive & 114 & 3.55 & 1.624 & 0.152 \\
\hline & after test drive & 114 & 5.48 & 1.830 & 0.171 \\
\hline \multirow{2}{*}{$\begin{array}{l}\text { estimation of running } \\
\text { cost }\end{array}$} & before test drive & 114 & 5.37 & 2.130 & 0.199 \\
\hline & after test drive & 114 & 6.19 & 1.932 & 0.181 \\
\hline \multirow{2}{*}{ safety } & before test drive & 114 & 7.31 & 1.815 & 0.170 \\
\hline & after test drive & 114 & 7.70 & 1.667 & 0.156 \\
\hline \multirow{2}{*}{ range in $\mathrm{km}$} & before test drive & 114 & 3.73 & 1.806 & 0.169 \\
\hline & after test drive & 114 & 4.25 & 2.068 & 0.194 \\
\hline \multirow{2}{*}{$\begin{array}{l}\text { reliability of the electric } \\
\text { car and battery }\end{array}$} & before test drive & 114 & 5.22 & 1.779 & 0.167 \\
\hline & after test drive & 114 & 6.01 & 1.948 & 0.182 \\
\hline
\end{tabular}


Table 3. Cont.

\begin{tabular}{cccccc}
\hline \multirow{2}{*}{ Variable } & \multicolumn{5}{c}{ Group Statistics } \\
\hline \multirow{2}{*}{ charging times } & N & Mean & Std. Deviation & Std. Error Mean \\
\hline \multirow{2}{*}{$\begin{array}{c}\text { comfort of charging } \\
\text { procedure }\end{array}$} & before test drive & 114 & 4.18 & 1.934 & 0.181 \\
& after test drive & 114 & 4.26 & 2.166 & 0.203 \\
\hline \multirow{2}{*}{ public charging } & before test drive & 114 & 6.82 & 2.268 & 0.212 \\
& after test drive & 114 & 6.86 & 2.319 & 0.217 \\
\hline \multirow{2}{*}{ charging at home } & before test drive & 114 & 4.32 & 2.290 & 0.214 \\
& after test drive & 114 & 4.59 & 2.241 & 0.210 \\
\hline \multirow{2}{*}{ acceleration and driving } & before test drive & 114 & 6.04 & 2.569 & 0.241 \\
pleasure & after test drive & 114 & 6.59 & 2.478 & 0.232 \\
\hline \multirow{2}{*}{ driving comfort } & before test drive & 114 & 6.82 & 2.024 & 0.190 \\
& after test drive & 114 & 8.61 & 1.392 & 0.130 \\
\hline \multirow{2}{*}{ maximum speed in $\mathrm{km} / \mathrm{h}$} & before test drive & 114 & 8.03 & 1.727 & 0.162 \\
& after test drive & 114 & 8.95 & 1.128 & 0.106 \\
\hline \multirow{2}{*}{ eco friendliness of } & before test drive & 114 & 6.13 & 1.976 & 0.185 \\
electric cars & after test drive & 114 & 6.76 & 2.117 & 0.198 \\
\hline
\end{tabular}

Source: Own study $(\mathrm{n}=114)$.

In total, 16 categories presented in Table 3 show a change in the average value before and after the test drive. It can be observed that no value developed negatively; rather, an increase in factor perception was observed. The table below shows the increase of the mean of the evaluation factors in $\%$ from the highest to the lowest one (Table 4). The highest increase is noticed in the "estimation of price" (by 54\%), followed by "willingness to purchase an electric car" and "knowledge about electric cars" (both by $41 \%$ ), as well as "acceleration and driving pleasure" (by $26 \%$ ); the lowest factors, with almost no increase, are "eco friendliness" and "charging times" (both by $2 \%$ ), and "comfort of charging procedure", by $1 \%$ only.

Table 4. Increase of evaluation factors in \%. Source: Own study $(\mathrm{n}=114)$.

\begin{tabular}{cc}
\hline Factors & Increase \\
\hline estimation of price & 54 \\
willingness to purchase an electric car & 41 \\
knowledge about electric cars & 41 \\
acceleration and driving pleasure & 26 \\
estimation of running cost & 15 \\
reliability of the electric car and battery & 15 \\
range in km & 14 \\
driving comfort & 11 \\
general attitude toward electric cars & 11 \\
maximum speed in km/h & 10 \\
charging at home & 9 \\
public charging & 6 \\
safety & 5 \\
eco friendliness of electric cars & 2 \\
charging times & 2 \\
comfort of charging procedure & 1 \\
\hline
\end{tabular}


We now examined whether all questions from the first hypothesis can be combined into scores. If possible, the hypothesis was also evaluated on the basis of the summarized data. For this purpose, the Cronbach's Alpha was calculated (Table 5).

Table 5. Cronbach's Alpha I.

\begin{tabular}{|c|c|c|c|c|}
\hline \multicolumn{5}{|c|}{ Reliability Statistics } \\
\hline Cronbach's Alpha & \multicolumn{2}{|c|}{ N of Items } & & \\
\hline 0.805 & \multicolumn{2}{|c|}{15} & & \\
\hline \multicolumn{5}{|c|}{ Item-Total Statistics } \\
\hline (before test drive) & $\begin{array}{l}\text { Scale Mean if } \\
\text { Item Deleted }\end{array}$ & $\begin{array}{l}\text { Scale Variance } \\
\text { if Item Deleted }\end{array}$ & $\begin{array}{c}\text { Corrected } \\
\text { Item-Total } \\
\text { Correlation }\end{array}$ & $\begin{array}{l}\text { Cronbach's Alpha } \\
\text { if Item Deleted }\end{array}$ \\
\hline general attitude toward electric cars & 79.04 & 217.741 & 0.523 & 0.786 \\
\hline knowledge about electric cars & 81.73 & 242.023 & 0.121 & 0.815 \\
\hline estimation of price before test drive & 82.35 & 237.079 & 0.287 & 0.802 \\
\hline estimation of running cost & 80.54 & 228.092 & 0.333 & 0.800 \\
\hline safety & 78.60 & 230.119 & 0.375 & 0.797 \\
\hline range in $\mathrm{km}$ & 82.18 & 224.482 & 0.486 & 0.789 \\
\hline reliability of the electric car and battery & 80.68 & 225.138 & 0.483 & 0.790 \\
\hline charging times & 81.73 & 221.633 & 0.498 & 0.788 \\
\hline comfort of charging procedure & 79.09 & 210.594 & 0.582 & 0.780 \\
\hline public charging & 81.59 & 213.802 & 0.523 & 0.785 \\
\hline charging at home & 79.87 & 211.938 & 0.475 & 0.789 \\
\hline acceleration and driving pleasure & 79.09 & 220.824 & 0.484 & 0.789 \\
\hline driving comfort & 77.88 & 228.870 & 0.425 & 0.794 \\
\hline maximum speed in $\mathrm{km} / \mathrm{h}$ & 79.77 & 223.505 & 0.451 & 0.791 \\
\hline eco friendliness of electric cars & 78.53 & 230.252 & 0.239 & 0.810 \\
\hline
\end{tabular}

Source: Own study ( $\mathrm{n}=114)$.

Cronbach's Alpha indicates how a summary of the individual questions makes sense statistically. The maximum value is 1.0. The larger the value, the more suitable the summary. A value from 0.6 to 0.7 can be interpreted as a useful summary [97]. Due to low selectivity, three values (knowledge about electric cars, estimation of price before test drive, and eco-friendliness of electric cars) were selected. The result of the Cronbach's Alpha II is provided in Table 6.

Table 6. Cronbach's Alpha II.

\begin{tabular}{|c|c|c|c|c|}
\hline \multicolumn{5}{|c|}{ Reliability Statistics } \\
\hline Cronbach's Alpha & \multicolumn{2}{|c|}{ N of Items } & & \\
\hline 0.819 & \multicolumn{2}{|c|}{12} & & \\
\hline \multicolumn{5}{|c|}{ Item-Total Statistics } \\
\hline (before test drive) & $\begin{array}{l}\text { Scale Mean if } \\
\text { Item Deleted }\end{array}$ & $\begin{array}{l}\text { Scale Variance } \\
\text { if Item Deleted }\end{array}$ & $\begin{array}{l}\text { Corrected } \\
\text { Item-Total } \\
\text { Correlation }\end{array}$ & $\begin{array}{l}\text { Cronbach's Alpha } \\
\text { if Item Deleted }\end{array}$ \\
\hline general attitude toward electric cars & 63.94 & 167.987 & 0.546 & 0.799 \\
\hline estimation of running cost & 65.43 & 182.035 & 0.262 & 0.824 \\
\hline safety & 63.49 & 178.394 & 0.411 & 0.810 \\
\hline range in $\mathrm{km}$ & 67.07 & 174.862 & 0.492 & 0.804 \\
\hline reliability of the electric car and battery & 65.58 & 174.494 & 0.510 & 0.803 \\
\hline charging times & 66.62 & 173.635 & 0.476 & 0.805 \\
\hline comfort of charging procedure & 63.98 & 164.690 & 0.546 & 0.799 \\
\hline public charging & 66.48 & 167.119 & 0.494 & 0.804 \\
\hline charging at home & 64.76 & 163.191 & 0.485 & 0.806 \\
\hline acceleration and driving pleasure & 63.98 & 169.628 & 0.529 & 0.801 \\
\hline driving comfort & 62.77 & 177.735 & 0.454 & 0.807 \\
\hline maximum speed in $\mathrm{km} / \mathrm{h}$ & 64.67 & 172.631 & 0.483 & 0.805 \\
\hline
\end{tabular}


The value for "estimated running cost" before the test drive displayed a low selectivity. Therefore, the value was eliminated. The next Cronbach's Alpha was estimated (Table 7).

Table 7. Cronbach's Alpha III.

\begin{tabular}{|c|c|c|c|c|}
\hline \multicolumn{5}{|c|}{ Reliability Statistics } \\
\hline Cronbach's Alpha & \multicolumn{2}{|c|}{$\mathrm{N}$ of Items } & & \\
\hline 0.824 & \multicolumn{2}{|c|}{11} & & \\
\hline \multicolumn{5}{|c|}{ Item-Total Statistics } \\
\hline (before test drive) & $\begin{array}{l}\text { Scale Mean if } \\
\text { Item Deleted }\end{array}$ & $\begin{array}{l}\text { Scale Variance } \\
\text { if Item Deleted }\end{array}$ & $\begin{array}{c}\text { Corrected } \\
\text { Item-Total } \\
\text { Correlation }\end{array}$ & $\begin{array}{l}\text { Cronbach's Alpha } \\
\text { if Item Deleted }\end{array}$ \\
\hline $\begin{array}{l}\text { general attitude toward electric cars } \\
\text { before test drive }\end{array}$ & 58.57 & 149.291 & 0.561 & 0.803 \\
\hline safety & 58.12 & 159.737 & 0.414 & 0.816 \\
\hline range in $\mathrm{km}$ & 61.70 & 156.406 & 0.495 & 0.809 \\
\hline reliability of the electric car and battery & 60.21 & 157.141 & 0.487 & 0.810 \\
\hline charging times & 61.25 & 154.775 & 0.489 & 0.810 \\
\hline comfort of charging procedure & 58.61 & 146.823 & 0.547 & 0.804 \\
\hline public charging & 61.11 & 148.863 & 0.500 & 0.809 \\
\hline charging at home & 59.39 & 146.153 & 0.471 & 0.814 \\
\hline acceleration and driving pleasure & 58.61 & 151.938 & 0.521 & 0.807 \\
\hline driving comfort & 57.40 & 159.163 & 0.457 & 0.813 \\
\hline maximum speed in $\mathrm{km} / \mathrm{h}$ & 59.30 & 153.751 & 0.498 & 0.809 \\
\hline
\end{tabular}

Source: Own study ( $\mathrm{n}=114)$.

The total selectivity was bigger than 4 . Also, Cronbach's Alpha, with a value of 0.824 , displayed a good value for the 11 items. A summary of these values as a score can be justified (Table 8).

Table 8. Score before and after the test drive.

\begin{tabular}{|c|c|c|c|}
\hline \multicolumn{4}{|c|}{ Statistics } \\
\hline \multicolumn{2}{|r|}{ Variable } & Score Before Test Drive & Score after Test Drive \\
\hline \multirow{7}{*}{$\mathrm{N}$} & Valid & 114 & 114 \\
\hline & Missing & 0 & 0 \\
\hline & Mean & 5.9482 & 6.5638 \\
\hline & Median & 5.8636 & 6.5455 \\
\hline & Std. Deviation & 1.22655 & 1.24866 \\
\hline & Minimum & 2.45 & 3.45 \\
\hline & Maximum & 8.64 & 9.82 \\
\hline
\end{tabular}

Source: Own study $(\mathrm{n}=114)$.

Our next step was testing whether an underlying population was normally distributed. The Kolmogorov-Smirnov and the Shapiro-Wilk tests were applied (Table 9). A significant $p$-value stands for a violation of the normal distribution. In this case, both tests were not significant [98]. With this observation, it can be concluded that the data is normally distributed. This can also be noticed within the Q.Q plots [99], represented below, before and after the test drive (Figure 3). 
Table 9. Test of normal distribution.

\begin{tabular}{|c|c|c|c|c|c|c|}
\hline \multicolumn{7}{|c|}{ Tests of Normality } \\
\hline \multirow{2}{*}{ Variable } & \multicolumn{3}{|c|}{ Kolmogorov-Smirnov $^{a}$} & \multicolumn{3}{|c|}{ Shapiro-Wilk } \\
\hline & Statistic & df & Sig. & Statistic & df & Sig. \\
\hline Score before test drive & 0.065 & 114 & $0.200 *$ & 0.989 & 114 & 0.512 \\
\hline Score after test drive & 0.051 & 114 & $0.200 *$ & 0.992 & 114 & 0.740 \\
\hline
\end{tabular}
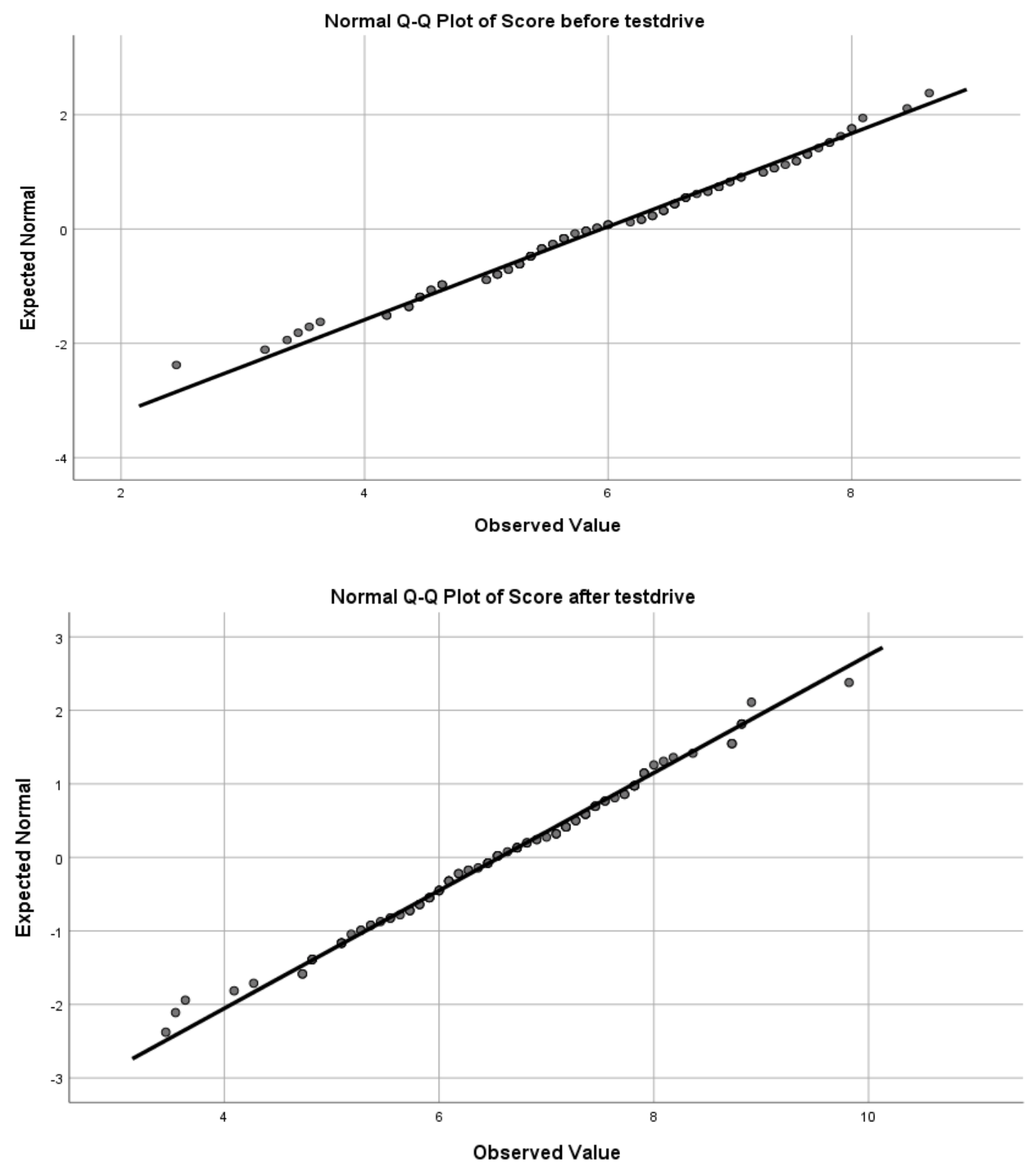

Figure 3. Q-Q plots before and after the test drive. Source: Own study ( $\mathrm{n}=114)$.

Hypothesis 1 stated that a short test drive experience with a BEV increases the positive attitude towards electric cars. To check if there was a difference between the values before and after the test drive, the Wilcoxon test was used (Table 10). 
Table 10. Wilcoxon test H1 I.

\begin{tabular}{|c|c|c|c|c|}
\hline \multicolumn{5}{|c|}{ Ranks } \\
\hline \multicolumn{2}{|l|}{ Variable } & \multirow{2}{*}{$\frac{\mathbf{N}}{24^{\mathrm{a}}}$} & Mean Rank & \multirow{2}{*}{$\frac{\text { Sum of Ranks }}{949.50}$} \\
\hline \multirow{4}{*}{$\begin{array}{l}\text { general attitude toward electric cars } \\
\text { after test drive - general attitude } \\
\text { toward electric cars before test drive }\end{array}$} & Negative Ranks & & 39.56 & \\
\hline & Positive Ranks & $62^{b}$ & 45.02 & 2791.50 \\
\hline & Ties & $28^{c}$ & & \\
\hline & Total & 114 & & \\
\hline \multirow{4}{*}{$\begin{array}{l}\text { knowledge about electric cars after } \\
\text { test drive - knowledge about electric } \\
\text { cars before test drive }\end{array}$} & Negative Ranks & $8^{d}$ & 23.63 & 189.00 \\
\hline & Positive Ranks & $76^{\mathrm{e}}$ & 44.49 & 3381.00 \\
\hline & Ties & $30^{\mathrm{f}}$ & & \\
\hline & Total & 114 & & \\
\hline \multirow{4}{*}{$\begin{array}{l}\text { estimation of price after test drive - } \\
\text { estimation of price before test drive }\end{array}$} & Negative Ranks & $9 \mathrm{~g}$ & 40.89 & 368.00 \\
\hline & Positive Ranks & $82^{h}$ & 46.56 & 3818.00 \\
\hline & Ties & $23^{\mathrm{i}}$ & & \\
\hline & Total & 114 & & \\
\hline \multirow{4}{*}{$\begin{array}{l}\text { estimation of running cost after test } \\
\text { drive - estimation of running cost } \\
\text { before test drive }\end{array}$} & Negative Ranks & $26^{\mathrm{j}}$ & 33.44 & 869.50 \\
\hline & Positive Ranks & $53^{k}$ & 43.22 & 2290.50 \\
\hline & Ties & $35^{1}$ & & \\
\hline & Total & 114 & & \\
\hline \multirow{4}{*}{$\begin{array}{l}\text { safety after test drive after test drive - } \\
\text { safety before test drive }\end{array}$} & Negative Ranks & $30^{\mathrm{m}}$ & 31.47 & 944.00 \\
\hline & Positive Ranks & $42^{n}$ & 40.10 & 1684.00 \\
\hline & Ties & $42^{\circ}$ & & \\
\hline & Total & 114 & & \\
\hline \multirow{4}{*}{$\begin{array}{l}\text { range in } \mathrm{km} \text { after test drive - range in } \\
\mathrm{km} \text { before test drive }\end{array}$} & Negative Ranks & $29 \mathrm{p}$ & 42.38 & 1229.00 \\
\hline & Positive Ranks & $55 \mathrm{q}$ & 42.56 & 2341.00 \\
\hline & Ties & $30^{r}$ & & \\
\hline & Total & 114 & & \\
\hline \multirow{4}{*}{$\begin{array}{l}\text { reliability of the electric car and batter } \\
\text { after test drive - reliability of the } \\
\text { electric car and batter before test drive }\end{array}$} & Negative Ranks & $26^{s}$ & 36.21 & 941.50 \\
\hline & Positive Ranks & $59^{t}$ & 45.99 & 2713.50 \\
\hline & Ties & $29^{u}$ & & \\
\hline & Total & 114 & & \\
\hline \multirow{4}{*}{$\begin{array}{l}\text { charging times after test drive - } \\
\text { charging times before test drive }\end{array}$} & Negative Ranks & $42 \mathrm{v}$ & 42.07 & 1767.00 \\
\hline & Positive Ranks & $43^{w}$ & 43.91 & 1888.00 \\
\hline & Ties & $29^{x}$ & & \\
\hline & Total & 114 & & \\
\hline \multirow{4}{*}{$\begin{array}{l}\text { comfort of charging procedure after } \\
\text { test drive - comfort of charging } \\
\text { procedure before test drive }\end{array}$} & Negative Ranks & $44^{\mathrm{y}}$ & 38.57 & 1697.00 \\
\hline & Positive Ranks & $39^{z}$ & 45.87 & 1789.00 \\
\hline & Ties & 31 aa & & \\
\hline & Total & 114 & & \\
\hline \multirow{4}{*}{$\begin{array}{l}\text { public charging after test drive - } \\
\text { public charging before test drive }\end{array}$} & Negative Ranks & $34^{\mathrm{ab}}$ & 34.44 & 1171.00 \\
\hline & Positive Ranks & $40^{\mathrm{ac}}$ & 40.10 & 1604.00 \\
\hline & Ties & $40^{\text {ad }}$ & & \\
\hline & Total & 114 & & \\
\hline \multirow{4}{*}{$\begin{array}{l}\text { charging at home after test drive - } \\
\text { charging at home before test drive }\end{array}$} & Negative Ranks & 30 ae & 41.95 & 1258.50 \\
\hline & Positive Ranks & $54^{\text {af }}$ & 42.81 & 2311.50 \\
\hline & Ties & $30^{\mathrm{ag}}$ & & \\
\hline & Total & 114 & & \\
\hline \multirow{4}{*}{$\begin{array}{l}\text { acceleration and driving pleasure } \\
\text { after test drive - acceleration and } \\
\text { driving pleasure before test drive }\end{array}$} & Negative Ranks & $16^{\mathrm{ah}}$ & 32.75 & 524.00 \\
\hline & Positive Ranks & 79 ai & 51.09 & 4036.00 \\
\hline & Ties & $19^{\text {aj }}$ & & \\
\hline & Total & 114 & & \\
\hline \multirow{4}{*}{$\begin{array}{l}\text { driving comfort after test drive - } \\
\text { driving comfort before test drive }\end{array}$} & Negative Ranks & $21^{\mathrm{ak}}$ & 28.83 & 605.50 \\
\hline & Positive Ranks & $56^{\mathrm{al}}$ & 42.81 & 2397.50 \\
\hline & Ties & $37^{\mathrm{am}}$ & & \\
\hline & Total & 114 & & \\
\hline & Negative Ranks & 32 an & 38.75 & 1240.00 \\
\hline maximum speed in $\mathrm{km} / \mathrm{h}$ after test & Positive Ranks & $55^{\text {ao }}$ & 47.05 & 2588.00 \\
\hline drive - maximum speed in km/h & Ties & 27 ap & & \\
\hline before test drive & Total & 114 & & \\
\hline
\end{tabular}


Table 10. Cont.

\begin{tabular}{|c|c|c|c|c|}
\hline \multicolumn{5}{|c|}{ Ranks } \\
\hline Variable & & $\mathbf{N}$ & Mean Rank & Sum of Ranks \\
\hline \multirow{4}{*}{$\begin{array}{l}\text { eco friendliness of electric cars after } \\
\text { test drive - eco friendliness of electric } \\
\text { cars before test drive }\end{array}$} & Negative Ranks & $38^{\mathrm{aq}}$ & 36.86 & 1400.50 \\
\hline & Positive Ranks & $40^{\text {ar }}$ & 42.01 & 1680.50 \\
\hline & Ties & $36^{\text {as }}$ & & \\
\hline & Total & 114 & & \\
\hline
\end{tabular}

a General attitude toward electric cars after test drive $<$ General attitude toward electric cars before test drive.

${ }^{b}$ General attitude toward electric cars after test drive $>$ General attitude toward electric cars before test drive.

${ }^{c}$ General attitude toward electric cars after test drive $=$ General attitude toward electric cars before test drive.

${ }^{\mathrm{d}}$ knowledge about electric cars after test drive $<$ knowledge about electric cars before test drive. ${ }^{\mathrm{e}}$ knowledge about electric cars after test drive $>$ knowledge about electric cars before test drive. ${ }^{\mathrm{f}}$ knowledge about electric cars after test drive $=$ knowledge about electric cars before test drive. ${ }^{g}$ estimation of price after test drive $<$ estimation of price before test drive. ${ }^{h}$ estimation of price after test drive $>$ estimation of price before test drive. ${ }^{\mathrm{i}}$ estimation of price after test drive $=$ estimation of price before test drive. ${ }^{j}$ estimation of running cost after test drive $<$ estimation of running cost before test drive. ${ }^{k}$ estimation of running cost after test drive $>$ estimation of running cost before test drive. ${ }^{1}$ estimation of running cost after test drive $=$ estimation of running cost before test drive. ${ }^{m}$ safety after test drive after test drive $<$ safety before test drive. ${ }^{\mathrm{n}}$ safety after test drive after test drive $>$ safety before test drive. ${ }^{\circ}$ safety after test drive after test drive $=$ safety before test drive. ${ }^{\mathrm{P}}$ range in $\mathrm{km}$ after test drive $<$ range in $\mathrm{km}$ before test drive. ${ }^{\mathrm{q}}$ range in $\mathrm{km}$ after test drive $>$ range in $\mathrm{km}$ before test drive. ${ }^{\mathrm{r}}$ range in $\mathrm{km}$ after test drive $=$ range in $\mathrm{km}$ before test drive. ${ }^{\mathrm{s}}$ reliability of the electric car and batter after test drive $<$ reliability of the electric car and batter before test drive. ${ }^{t}$ reliability of the electric car and batter after test drive $>$ reliability of the electric car and batter before test drive. " reliability of the electric car and batter after test drive = reliability of the electric car and batter before test drive. ${ }^{\mathrm{v}}$ charging times after test drive $<$ charging times before test drive. ${ }^{\mathrm{w}}$ charging times after test drive $>$ charging times before test drive. ${ }^{x}$ charging times after test drive $=$ charging times before test drive. ${ }^{\mathrm{y}}$ comfort of charging procedure after test drive $<$ comfort of charging procedure before test drive. ${ }^{\mathrm{z}}$ comfort of charging procedure after test drive $>$ comfort of charging procedure before test drive. ${ }^{\text {aa }}$ comfort of charging procedure after test drive $=$ comfort of charging procedure before test drive. ${ }^{\mathrm{ab}}$ public charging after test drive $<$ public charging before test drive. ${ }^{\mathrm{ac}}$ public charging after test drive $>$ public charging before test drive. ${ }^{\text {ad }}$ public charging after test drive = public charging before test drive. ae charging at home after test drive $<$ charging at home before test drive. ${ }^{\text {af }}$ charging at home after test drive $>$ charging at home before test drive. ${ }^{\text {ag }}$ charging at home after test drive $=$ charging at home before test drive. ${ }^{\text {ah }}$ acceleration and driving pleasure after test drive $<$ acceleration and driving pleasure before test drive. ${ }^{\text {ai }}$ acceleration and driving pleasure after test drive $>$ acceleration and driving pleasure before test drive. ${ }^{\text {aj }}$ acceleration and driving pleasure after test drive $=$ acceleration and driving pleasure before test drive. ${ }^{a k}$ driving comfort after test drive $<$ driving comfort before test drive. ${ }^{\text {al }}$ driving comfort after test drive $>$ driving comfort before test drive. ${ }^{\text {am }}$ driving comfort after test drive $=$ driving comfort before test drive. an maximum speed in $\mathrm{kmh}$ after test drive $<$ maximum speed in $\mathrm{kmh}$ before test drive. ao maximum speed in $\mathrm{kmh}$ after test drive $>$ maximum speed in $\mathrm{kmh}$ before test drive. ${ }^{\text {ap }}$ maximum speed in $\mathrm{kmh}$ after test drive $=$ maximum speed in kmh before test drive ${ }^{\text {aq }}$ eco friendliness of electric cars after test drive < eco-friendliness of electric cars before test drive. ${ }^{\text {ar }}$ eco-friendliness of electric cars after test drive $>$ eco-friendliness of electric cars before test drive. as eco-friendliness of electric cars after test drive $=$ eco-friendliness of electric cars before test drive.

The majority of values showed a significant change while differences in the categories of "charging times", "comfort of charging procedure", "public charging", and "eco-friendliness" were not significant (Table 11). On the basis of these analyses, the statement can be made that $\mathrm{H} 1$ was confirmed only when the abovementioned four areas were not included.

Table 11. Wilcoxon test H1 II.

\begin{tabular}{lcc}
\hline \multicolumn{1}{c}{ Test Statistics $^{\mathrm{a}}$} & \\
\hline \multicolumn{1}{c}{ Variable } & $\mathrm{Z}$ & Asymp. Sig. (2-Tailed) \\
\hline $\begin{array}{l}\text { General attitude toward electric cars after test drive }- \\
\text { General attitude toward electric cars before test drive }\end{array}$ & $-4.019^{\mathrm{b}}$ & 0.000 \\
\hline $\begin{array}{l}\text { knowledge about electric cars after test drive }- \\
\text { knowledge about electric cars before test drive }\end{array}$ & $-7.168^{\mathrm{b}}$ & 0.000 \\
\hline $\begin{array}{l}\text { estimation of price after test drive - estimation of price } \\
\text { before test drive }\end{array}$ & $-6.862^{\mathrm{b}}$ & 0.000 \\
\hline $\begin{array}{l}\text { estimation of running cost after test drive - estimation } \\
\text { of running cost before test drive }\end{array}$ & $-3.497^{\mathrm{b}}$ & 0.000 \\
\hline
\end{tabular}


Table 11. Cont.

\begin{tabular}{|c|c|c|}
\hline \multicolumn{3}{|c|}{ Test Statistics ${ }^{\mathbf{a}}$} \\
\hline Variable & $\mathbf{Z}$ & Asymp. Sig. (2-Tailed) \\
\hline $\begin{array}{l}\text { safety after test drive after test drive - safety before } \\
\text { test drive }\end{array}$ & $-2.097^{b}$ & 0.036 \\
\hline $\begin{array}{l}\text { range in } \mathrm{km} \text { after test drive - range in } \mathrm{km} \text { before } \\
\text { test drive }\end{array}$ & $-2.516^{b}$ & 0.012 \\
\hline $\begin{array}{l}\text { reliability of the electric car and batter after test drive - } \\
\text { reliability of the electric car and batter before test drive }\end{array}$ & $-3.923^{b}$ & 0.000 \\
\hline $\begin{array}{l}\text { charging times after test drive - charging times before } \\
\text { test drive }\end{array}$ & $-0.268^{b}$ & 0.788 \\
\hline $\begin{array}{l}\text { comfort of charging procedure after test drive - } \\
\text { comfort of charging procedure before test drive }\end{array}$ & $-0.211^{b}$ & 0.833 \\
\hline $\begin{array}{l}\text { public charging after test drive - public charging } \\
\text { before test drive }\end{array}$ & $-1.188^{b}$ & 0.235 \\
\hline $\begin{array}{l}\text { charging at home after test drive - charging at home } \\
\text { before test drive }\end{array}$ & $-2.368^{b}$ & 0.018 \\
\hline $\begin{array}{l}\text { acceleration and driving pleasure after test drive - } \\
\text { acceleration and driving pleasure before test drive }\end{array}$ & $-6.556^{b}$ & 0.000 \\
\hline $\begin{array}{l}\text { driving comfort after test drive - driving comfort } \\
\text { before test drive }\end{array}$ & $-4.625^{b}$ & 0.000 \\
\hline $\begin{array}{l}\text { maximum speed in } \mathrm{kmh} \text { after test drive - maximum } \\
\text { speed in kmh before test drive }\end{array}$ & $-2.889^{b}$ & 0.004 \\
\hline $\begin{array}{l}\text { eco friendliness of electric cars after test drive - eco } \\
\text { friendliness of electric cars before test drive }\end{array}$ & $-0.708^{b}$ & 0.479 \\
\hline
\end{tabular}

${ }^{a}$ Wilcoxon Signed Ranks Test; ${ }^{b}$ Based on negative ranks. Source: Own study $(\mathrm{n}=114)$.

Hypothesis 2 stated that a short test drive experience with a BEV increases the purchase intent towards electric vehicles. In the following, the Wilcoxon test was used to clarify whether there was an overall change (Table 12).

Table 12. Wilcoxon test H2 I.

\begin{tabular}{ccccc}
\hline \multicolumn{5}{c}{ Ranks } \\
Variable & & N & Mean Rank & Sum of Ranks \\
\hline willingness to purchase an & Negative Ranks & $13^{\mathrm{a}}$ & 26.31 & 342.00 \\
electric car after test drive - & Positive Ranks & $72^{\mathrm{b}}$ & 46.01 & 3313.00 \\
willingness to purchase an & Ties & $29^{\mathrm{c}}$ & & \\
electric car before test drive & Total & 114 & &
\end{tabular}

${ }^{a}$ willingness to purchase an electric car after test drive $<$ willingness to purchase an electric car before test drive.

$\mathrm{b}$ willingness to purchase an electric car after test drive $>$ willingness to purchase an electric car before test drive.

${ }^{c}$ willingness to purchase an electric car after test drive $=$ willingness to purchase an electric car before test drive.

Source: Own study $(\mathrm{n}=114)$.

If one compares the mean values mentioned in Table 3, it is possible to observe that this parameter increased by $41 \%$, from 3.79 to 5.35 . The abovementioned test shows the significance of these values (Table 13) and therefore $\mathrm{H} 2$ can be confirmed. 
Table 13. Wilcoxon test H2 II.

\begin{tabular}{cc}
\hline & Test Statistics $^{\text {a }}$ \\
\hline & willingness to purchase an electric car after test drive - \\
$\mathrm{Z}$ & willingness to purchase an electric car before test drive \\
Asymp. Sig. (2-tailed) & $-6.555^{\mathrm{b}}$ \\
\hline${ }^{\mathrm{a}}$ Wilcoxon Signed Ranks Test. ${ }^{\mathrm{b}}$ Based on negative ranks. Source: Own study $(\mathrm{n}=114)$.
\end{tabular}

In the following, various univariate analyses were performed to determine whether any variables significantly influenced the result. The Mann-Whitney $U$ test was used to analyze the effect of gender (Table 14). In addition, other factors, such as age, education level, and the number of cars in the household, were examined in the context of correlations.

Table 14. Mann-Whitney U test H2 I.

\begin{tabular}{ccccc}
\hline \multicolumn{5}{c}{ Ranks } \\
\hline Variable & Gender & N & Mean Rank & Sum of Ranks \\
\hline willingness to & male & 62 & 54.65 & 3388.00 \\
purchase an electric & female & 52 & 60.90 & 3167.00 \\
car before test drive & Total & 114 & & 3452.50 \\
\hline willingness to & male & 62 & 55.69 & 3102.50 \\
purchase an electric & female & 52 & 59.66 & \\
car after test drive & Total & 114 & &
\end{tabular}

Both $p$-values were not significant (Table 15); therefore, a connection between gender and test results could not be proven. No significant correlations with age, education level, number of cars in the household, or estimated income could be identified (Table 16).

Table 15. Mann-Whitney U test H2 II.

\begin{tabular}{ccc}
\hline \multicolumn{3}{c}{ Test Statistics $^{\text {a }}$} \\
\hline & $\begin{array}{c}\text { Willingness to Purchase an } \\
\text { Electric Car before Test Drive }\end{array}$ & $\begin{array}{c}\text { Willingness to Purchase an } \\
\text { Electric Car after Test Drive }\end{array}$ \\
\hline Mann-Whitney U & 1435.000 & 1499.500 \\
Wilcoxon W & 3388.000 & 3452.500 \\
Z & -1.019 & -0.644 \\
Asymp. Sig. (2-tailed) & 0.308 & 0.519 \\
\hline
\end{tabular}

${ }^{a}$ Grouping Variable: Gender. Source: Own study $(\mathrm{n}=114)$.

Table 16. Spearman's rho correlation $\mathrm{H} 2$.

\begin{tabular}{|c|c|c|c|c|c|c|}
\hline \multicolumn{7}{|c|}{ Correlations } \\
\hline \multirow{3}{*}{ Variable } & \multicolumn{6}{|c|}{ Spearman's Rho } \\
\hline & \multicolumn{3}{|c|}{$\begin{array}{l}\text { Willingness to Purchase an Electric Car } \\
\text { before Test Drive }\end{array}$} & \multicolumn{3}{|c|}{$\begin{array}{c}\text { Willingness to Purchase an Electric Car } \\
\text { after Test Drive }\end{array}$} \\
\hline & $\begin{array}{l}\text { Correlation } \\
\text { Coefficient }\end{array}$ & $\begin{array}{c}\text { Sig. } \\
\text { (2-Tailed) }\end{array}$ & $\mathbf{N}$ & $\begin{array}{l}\text { Correlation } \\
\text { Coefficient }\end{array}$ & $\begin{array}{c}\text { Sig. } \\
\text { (2-Tailed) }\end{array}$ & $\mathbf{N}$ \\
\hline Age & 0.061 & 0.520 & 114 & $0.198 *$ & 0.034 & 114 \\
\hline Education level & 0.037 & 0.698 & 114 & -0.044 & 0.641 & 114 \\
\hline $\begin{array}{l}\text { Number of cars } \\
\text { within the household }\end{array}$ & -0.069 & 0.467 & 114 & -0.079 & 0.404 & 114 \\
\hline Estimated income & -0.077 & 0.453 & 96 & -0.051 & 0.620 & 96 \\
\hline
\end{tabular}

* Correlation is significant at the 0.05 level (2-tailed). Source: Own study $(\mathrm{n}=114)$. 


\section{Discussion and Conclusions}

When observing the German vehicle market, it can be noticed that car manufacturers have not yet managed to establish a strong market position with BEVs. The reasons for this could be that the disadvantages (negative BEV performance factors) outweigh the advantages (positive BEV performance factors). Especially, range in $\mathrm{km}$, charging times, and infrastructure are major hindrance factors. TCO, environmental-friendliness, and driving characteristics can be evaluated positively, considering the current state of technology. Another explanation for the lack of market success could be the lack of experience of potential consumers.

The automotive industry is faced with the challenge of finding an optimal approach to BEV marketing. The innovation of electric cars needs to reach critical masses to be successful. Currently, innovators comprise the group targeted as the primary users of BEVs. Due to the novelty of the product, not many people have driven such a vehicle. In our assessment, an experience-based marketing strategy can tackle this problem. Our findings confirm the positive effects of utilizing multi-sensory marketing methods [81] to increase experiences with electric cars. This provides some valuable theoretical and practical contributions to the implementation of this marketing concept.

The effect of the test drives is noticeable, especially in some specific areas. Consumers can be convinced that the acquisition cost is lower than expected. Moreover, driving an electric car creates an opportunity to feel the driving characteristics that are marked by fast acceleration, increased driving pleasure, and higher comfort through the lower noise and absent gear changes. These tangible attributes are difficult to convey through a classical marketing approach that does not take advantage of direct experience. Furthermore, it is demonstrated that test drives increase the perception of range and confidence in engine/battery liability. These positive effects can be created by car manufacturers by offering direct experience in the form of test drives. In this way, they can increase potential customers' general attitudes and knowledge about BEVs.

Driving the vehicle enables experience-based learning. The knowledge gain is measurable. BEV manufacturers have the chance to explain innovations by making use of this direct contact with the product. The influence can be seen in the increased purchase intentions.

Similar to the results of previous studies [91,93-95] the outcomes of our field study suggest that a short test drive can raise the perception of electric vehicles in general. The analysis of the individual characteristics of electric cars reveals positive developments regarding the perception of acquisition costs $(+54 \%)$ and acceleration /driving pleasure $(+26 \%)$. Other increasing values are maintenance and energy cost $(+15 \%)$, engine/battery reliability and durability $(+15 \%)$, range in $\mathrm{km}$ $(14 \%)$, driving comfort $(+11 \%)$, top speed $(+10 \%)$, and charging at home $(+9 \%)$. It is worth noting the increased knowledge gained through the test drives. Our results show that utilizing sensory marketing concepts $[13-15,81,82]$ to increase general BEV value perception and raise customer purchase intent does not require long-term experiments, and that short test drives may appropriately serve this objective. Our results show that people changed their perception of BEVs by executing a short test drive. Moreover, Audi has already used this method to promote BEVs [100].

In addition to gains in perception and knowledge, the probability of considering a BEV within the next car purchase rises with a first-time experience. The willingness to purchase an electric vehicle increased by $41 \%$, which brings new insights after previous studies did not observe this effect [95].

The Norwegian government has succeeded in establishing this technology, with all its advantages and disadvantages. The price of artificial influence is a large subsidy expenditure. Our research reveals that other possible ways to support the acceptance of electric cars exist. In addition, an increasing development of battery technology can be observed, forecasting an increase in range. Moreover, prices for lithium should continue to fall.

The present study has several limitations, as it was conducted under certain restrictions that were related to limited financial resources and other factors. First of all, as noted above, the electric cars used for the experiment were provided by Volkswagen. It could be the case that the brand or product-specific characteristics influenced the results. The state of the charge of the battery could also 
have changed the results of the study. People who performed the test drive in the morning enjoyed a vehicle with a full range. The opposite was the case for people who drove at a later time in the day. Consequently, range anxiety could have had a negative influence on the results. Another limitation is the distance driven. Since there was no predefined route, the test subjects drove on different roads. Also, the exact driving times varied. A further variable in the experiment was the 20 instructors that executed the test drive. They were advised to represent a neutral viewpoint. However, this could not be proven. Lastly, all participants came from the North Rhine-Westphalia region, which is close to the city of Münster. In this respect, the sample may not be representative of the whole population of Germany.

We see at least three areas where research based on short BEV test-driving experiments could be enhanced to yield more insightful results. The first one would be to embrace richer conceptual frameworks combining sensual marketing and innovation management for BEV analysis. The second one is related to improving the research methodology, where the research separates the effect of the information that was given in the brochure from the effect of experience. The question is, for example, does an approach that only provides information without a test drive have a similar positive effect? Finally, our study should be extended to other regions of Germany and expanded to compare other BEV brands to identify differences and similarities, probably modifying the research methodology. Additionally, the goal of this study was to measure the change in value perception after a short 10-min test drive. Participants rated the BEV directly after driving. To get improved results, a third questionnaire should investigate the long-term effects. Moreover, the study should be periodically repeated due to constantly improving technology. In two years, the findings could be different from the results obtained today. Finally, new product releases from various BEV manufacturers are expected in 2020. Consumers have used and gotten used to petrol engines for more than 100 years. Changing such ingrained consumer attitudes takes time. Based on our results, it can be stated that the use of a short test drive could accelerate this process.

Author Contributions: Authors contributed equally: Formal analysis, F.H., M.S. and K.S.-D.; Funding acquisition, F.H. and K.S.-D.; Investigation, F.H., M.S. and K.S.-D.; Methodology, F.H. and M.S.; Project Administration, F.H. and K.S.-D.; Supervision, M.S.; Writing—original draft, F.H. and M.S.; Writing—review \& editing, F.H., M.S. and K.S.-D.; Visualization-F.H. and K.S.-D.

Funding: The project is financed within the framework of the program of the Minister of Science and Higher Education under the name "Regional Excellence Initiative" in the years 2019-2022, project number 001/RID/2018/19, the amount of financing PLN 10,684,000.00 and by the Institute of Management, University of Szczecin, statutory funds.

Acknowledgments: We are grateful to the Editors and anonymous Reviewers for valuable comments and suggestions.

Conflicts of Interest: The authors declare no conflicts of interest.

\section{References}

1. Carlucci, F.; Cirà, A.; Lanza, G. Hybrid Electric Vehicles: Some theoretical considerations on consumption behavior. Sustainability 2018, 10, 1302. [CrossRef]

2. Liao, F.; Molin, E.; van Wee, B. Consumer preferences for electric vehicles: A literature review. Transp. Rev. 2017, 37, 252-275. [CrossRef]

3. Li, Q.; Long, R.; Chen, H.; Geng, J. Low Purchase Willingness for Battery Electric Vehicles: Analysis and Simulation Based on the Fault Tree Model. Sustainability 2017, 9, 809. [CrossRef]

4. Burgess, M.; King, N.; Harris, M.; Lewis, E. Electric vehicle drivers' reported interactions with the public: Driving stereotype change? Transp. Res. Part F Traffic Psychol. Behav. 2013, 17, 33-44. [CrossRef]

5. Jensen, A.F.; Cherchi, E.; Mabit, S.L. On the stability of preferences and attitudes before and after experiencing an electric vehicle. Transp. Res. Part D Transp. Environ. 2013, 25, 24-32. [CrossRef]

6. Cocron, P.; Krems, J.F. Driver perceptions of the safety implications of quiet electric vehicles. Accid. Anal. Prev. 2013, 58, 122-131. [CrossRef] 
7. Schneider, U.; Dütschke, E.; Peters, A. How does the actual usage of electric vehicles influence consumer acceptance. In Evolutionary Paths towards the Mobility Patterns of the Future; Springer: Berlin/Heidelberg, Germany, 2014; pp. 49-66. [CrossRef]

8. Grönroos, C. Adopting a service logic for marketing. Mark. Theory 2006, 6, 317-333. [CrossRef]

9. Chakraborty, S.; Dobrzykowski, D. Examining value co-creation in healthcare purchasing: A supply chain view. Business: Theory Pract. 2014, 15, 179-190. [CrossRef]

10. Smaliukiene, R.; Chi-Shiun, L.; Sizovaite, I. Consumer value co-creation in online business: The case Grönroos of global travel services. J. Bus. Econ. Manag. 2014, 16, 325-339. [CrossRef]

11. Szarucki, M.; Menet, G. Service marketing, value co-creation and customer satisfaction in the airsoft industry: Case of a technology-based firm. Business. Manag. Educ. 2018, 16, 94-107. [CrossRef]

12. Aquilani, B.; Silvestri, C.; Ioppolo, G.; Ruggieri, A. The challenging transition to bio-economies: Towards a new framework integrating corporate sustainability and value co-creation. J. Clean. Prod. 2018, 171, 4001-4009. [CrossRef]

13. Moreira, A.; Fortes, N.; Santiago, R. Influence of sensory stimuli on brand experience, brand equity and purchase intention. J. Bus. Econ. Manag. 2017, 18, 68-83. [CrossRef]

14. Krishna, A. An integrative review of sensory marketing: Engaging the senses to affect perception, judgment and behavior. J. Consum. Psychol. 2012, 22, 332-351. [CrossRef]

15. Hultén, B. Sensory Marketing: Theoretical and Empirical Grounds; Routledge, Taylor \& Francis: New York, NY, USA, 2015.

16. Ma, S.C.; Fan, Y.; Guo, J.F.; Xu, J.H.; Zhu, J. Analysing online behaviour to determine Chinese consumers' preferences for electric vehicles. J. Clean. Prod. 2019, 229, 244-255. [CrossRef]

17. Li, W.; Long, R.; Chen, H.; Geng, J. A review of factors influencing consumer intentions to adopt battery electric vehicles. Renew. Sustain. Energy Rev. 2017, 78, 318-328. [CrossRef]

18. Bundesamt für Wirtschaft und Ausfuhrkontrolle. Elektromobilität und des-sen Förderung. 2016. Available online: http://www.bafa.de/DE/Energie/Energieeffizienz/Elektromobilitaet/elektromobilitaet_node.html (accessed on 9 June 2019).

19. Kraftfahrt Bundesamt. Kaufprämie für Elektroautos-Anträge nach Bauart. 2018. Available online: https:/www.hb.fh-muenster.de:2080/statistik/daten/studie/578352/umfrage/anzahl-der-beantragtenumweltboni-fuer-elektroautos-nach-bauart-in-deutschland/ (accessed on 9 June 2019).

20. Plötz, P.; Schneider, U.; Globisch, J.; Dütschke, E. Who will buy electric vehicles? Identifying early adopters in Germany. Transp. Res. Part A Policy Pract. 2014, 67, 96-109. [CrossRef]

21. De Rubens, G.Z. Who will buy electric vehicles after early adopters? Using machine learning to identify the electric vehicle mainstream market. Energy 2019, 172, 243-254. [CrossRef]

22. Sałabun, W.; Palczewski, K.; Wątróbski, J. Multicriteria approach to sustainable transport evaluation under incomplete knowledge: Electric Bikes Case Study. Sustainability 2019, 11, 3314. [CrossRef]

23. Haddadian, G.; Khodayar, M.; Shahidehpour, M. Accelerating the global adoption of electric vehicles: Barriers and drivers. Electr. J. 2015, 28, 53-68. [CrossRef]

24. Turcksin, L.; Mairesse, O.; Macharis, C. Private household demand for vehicles on alternative fuels and drive trains: A review. Eur. Transp. Res. Rev. 2013, 5, 149. [CrossRef]

25. Dudenhöffer, F.; Bussmann, L.; Dudenhöffer, K. Elektromobilität braucht intelligente Förderung. Wirtschaftsdienst 2012, 92, 274-279. [CrossRef]

26. German Federal Government. Development Goals of Electromobility in the Federal Republic Germany. 2012. Available online: https://www.bundesregierung.de/Content/DE/Infodienst/2012/10/2012-10-12elektromobilitaet/2012-10-12-elektromobilitaet.html (accessed on 8 June 2019).

27. Statistisches Bundesamt. Automobilindustrie-Beschäftigtenzahl in Deutschland Statistik. 2016. Available online: https:/www.hb.fh-muenster.de:2080/statistik/daten/studie/30703/umfrage/beschaeftigtenzahl-inder-automobilindustrie/ (accessed on 8 March 2018).

28. Foörderung von elektrisch betriebenen Fahrzeugen. Available online: https://www.bafa.de/SharedDocs/ Downloads/DE/Energie/emob_merkblatt_antrag_neu_2019.pdf?_blob=publicationFile\&v=5/(accessed on 8 October 2019).

29. Förderung für Elektroautos: Hier gibt es Geld. Available online: https://www.adac.de/rund-ums-fahrzeug/ elektromobilitaet/kaufen/foerderung-elektroautos/ (accessed on 8 October 2019). 
30. European Alternative Fuels Observatory: Registration numbers of BEV and PHEV in Norway. Available online: https://www.statista.com/statistics/1029872/newly-registered-plug-in-hybrid-and-battery-electriccars-in-norway/ (accessed on 9 June 2019).

31. Aasness, M.A.; Odeck, J. The increase of electric vehicle usage in Norway-Incentives and adverse effects. Eur. Transp. Res. Rev. 2015, 7, 34. [CrossRef]

32. Bjerkan, K.Y.; Nørbech, T.E.; Nordtømme, M.E. Incentives for promoting battery electric vehicle (BEV) adoption in Norway. Transp. Res. Part D Transp. Environ. 2016, 43, 169-180. [CrossRef]

33. Karle, A. Elektromobilität. Grundlagen und Praxis; Carl Hanser Verlag GmbH \& Co.: München, Germany, 2015.

34. Bobeth, S.; Matthies, E. Elektroautos. Top in Norwegen, Flop in Deutschland? Empfehlungen aus Sicht der Umweltpsychologie. GAIA-Ecol. Perspect. Sci. Soc. 2016, 25, 38-48. [CrossRef]

35. Egbue, O.; Long, S. Barriers to widespread adoption of electric vehicles. An analysis of consumer attitudes and perceptions. Energy Policy 2012, 48, 717-729. [CrossRef]

36. Federal Ministry for Economic Affairs and Energy. For a Future of Green Energy. 2018. Available online: http://www.bmwi.de/Redaktion/EN/Dossier/renewable-energy.html (accessed on 19 March 2018).

37. Ellingsen, L.A.-W.; Singh, B.; Strømman, A.H. The size and range effect. Lifecycle greenhouse gas emissions of electric vehicles. Environ. Res. Lett. 2016, 11, 54010. [CrossRef]

38. Qiao, Q.; Zhao, F.; Liu, Z.; Jiang, S.; Hao, H. Comparative study on life cycle $\mathrm{CO}_{2}$ emissions from the production of electric and conventional vehicles in China. Energy Procedia 2017, 105, 3584-3595. [CrossRef]

39. Peng, T.; Ou, X.; Yan, X. Development and application of an electric vehicles life-cycle energy consumption and greenhouse gas emissions analysis model. Chem. Eng. Res. Des. 2018, 131, 699-708. [CrossRef]

40. Axsen, J.; Orlebar, C.; Skippon, S. Social influence and consumer preference formation for pro-environmental technology: The case of a U.K. work-place electric-vehicle study. Ecol. Econ. 2013, 95, 96-107. [CrossRef]

41. Skippon, S.M. How consumer drivers construe vehicle performance: Implications for electric vehicles. Transp. Res. Part F Traffic Psychol. Behav. 2014, 23, 15-31. [CrossRef]

42. Palmer, K.; Tate, J.E.; Wadud, Z.; Nellthorp, J. Total cost of ownership and market share for hybrid and electric vehicles in the UK, US and Japan. Appl. Energy 2018, 209, 108-119. [CrossRef]

43. Hagman, J.; Ritzén, S.; Stier, J.J.; Susilo, Y. Total cost of ownership and its potential implications for battery electric vehicle diffusion. Res. Transp. Bus. Manag. 2016, 18, 11-17. [CrossRef]

44. Wu, G.; Inderbitzin, A.; Bening, C. Total cost of ownership of electric vehicles compared to conventional vehicles: A probabilistic analysis and projection across market segments. Energy Policy 2015, 80, 196-214. [CrossRef]

45. Rauh, N.; Franke, T.; Krems, J.F. First-time experience of critical range situations in BEV use and the positive effect of coping information. Transp. Res. Part F Traffic Psychol. Behav. 2017, 44, 30-41. [CrossRef]

46. Naumann, M.; Karl, R.C.; Truong, C.N.; Jossen, A.; Hesse, H.C. Lithium-ion battery cost analysis in PV-household application. Energy Procedia. 2015, 73, 37-47. [CrossRef]

47. Schmidt, O.; Hawkes, A.; Gambhir, A.; Staffell, I. The future cost of electrical energy storage based on experience rates. Nat. Energy 2017, 2, 17110. [CrossRef]

48. Nykvist, B.; Sprei, F.; Nilsson, M. Assessing the progress toward lower priced long range battery electric vehicles. Energy Policy 2019, 124, 144-155. [CrossRef]

49. Statista. Worldwide Price Status of Licium Ion Batteries and Estimation of Future Development. 2015. Available online: https:/www.hb.fh-muenster.de:2080/statistik/daten/studie/534429/umfrage/weltweitepreise-fuer-lithium-ionen-akkus/ (accessed on 25 July 2019).

50. Faria, R.; Moura, P.; Delgado, J.; de Almeida, A.T. A sustainability assessment of electric vehicles as a person-al mobility system. Energy Convers. Manag. 2012, 61, 19-30. [CrossRef]

51. German Customs. Taxes in Germany for Battery Electric Vehicles. 2018. Available online: http://www.zoll.de/DE/Fachthemen/Steuern/Verkehrsteuern/Kraftfahrzeugsteuer/Steuerverguenstigung/ Elektrofahrzeuge/elektrofahrzeuge_node.html (accessed on 25 July 2019).

52. Mruzek, M.; Gajdáč, I.; Kučera, L.; Barta, D. Analysis of Parameters Influencing Electric Vehicle Range. Procedia Eng. 2016, 134, 165-174. [CrossRef]

53. Proff, H.; Fojcik, T.M. Mobilität und Digitale Transformation: Technische und Betriebswirtschaftliche Aspekte; Springer: Wiesbaden, Germany, 2018; ISBN 978-3-658-20779-3.

54. Horrein, L.; Bouscayrol, A.; Lhomme, W.; Depature, C. Impact of heating system on the range of an electric vehicle. IEEE Trans. Veh. Technol. 2016, 66, 4668-4677. [CrossRef] 
55. Fetene, G.M.; Kaplan, S.; Mabit, S.L.; Jensen, A.F.; Prato, C.G. Harnessing big data for estimating the energy consumption and driving range of electric vehicles. Transp. Res. Part D Transp. Environ. 2017, 54, 1-11. [CrossRef]

56. Volkswagen. e-Golf: Charging Times. 2018. Available online: https://www.volkswagen.at/e-golf/ lademoeglichkeiten (accessed on 23 July 2019).

57. Vassileva, I.; Campillo, J. Adoption barriers for electric vehicles: Experiences from early adopters in Sweden. Energy 2017, 120, 632-641. [CrossRef]

58. Pedrosa, G.; Nobre, H. The influence of consumer mobility concerns on electric vehicle adoption. World Rev. Int. Transp. Res. 2019, 8, 366-390. [CrossRef]

59. Bonges, H.A.; Lusk, A.C. Addressing electric vehicle (EV) sales and range anxiety through parking layout, policy and regulation. Transp. Res. Part A Policy Pract. 2016, 83, 63-73. [CrossRef]

60. Ko, W.; Hahn, T.K. Analysis of consumer preferences for electric vehicles. IEEE Trans. Smart Grid 2013, 4, 437-442. [CrossRef]

61. Dudenhöffer, K. Akzeptanz von Elektroautos in Deutschland und China: Eine Untersuchung von Nutzungsintentionen im Anfangsstadium der Innovationsdiffusion; Springer: Wiesbaden, Germany, 2015. [CrossRef]

62. Kampker, A.; Vallée, D.; Schnettler, A. Elektromobilität. Grundlagen Einer Zukunftstechnologie; Springer: Berlin/Heidelberg, Germany, 2013.

63. Stelling-Kończak, A.; Hagenzieker, M.; Wee, B.V. Traffic sounds and cycling safety: The use of electronic devices by cyclists and the quietness of hybrid and electric cars. Transp. Rev. 2015, 35, 422-444. [CrossRef]

64. Hanke, C.; Hüelsmann, M.; Fornahl, D. Socio-economic aspects of electric vehicles: A literature review. In Evolutionary Paths Towards the Mobility Patterns of the Future; Springer: Berlin/Heidelberg, Germany, 2014; pp. 13-36. [CrossRef]

65. Fishbein, M.; Ajzen, I. Belief, Attitude, Intention and Behavior: An Introduction to Theory and Research; Addison-Wesley: Boston, MA, USA, 1975; ISBN 0201020890.

66. Kuß, A.; Tomczak, T. Käuferverhalten Eine marketingorientierte Einführung; UTB: Stuttgart, Germany, 2004; ISBN 3825239314.

67. Blackwell, R.D.; Miniard, P.W.; Engel, J.F. Consumer Behavior; Harcourt College Publishers: Fort Worth, TX, USA, 2001.

68. Simsekoglu, Ö. Socio-demographic characteristics, psychological factors and knowledge related to electric car use: A comparison between electric and conventional car drivers. Transp. Policy 2018, 72, 180-186. [CrossRef]

69. Nayum, A.; Klöckner, C.A.; Mehmetoglu, M. Comparison of socio-psychological characteristics of conventional and battery electric car buyers. Travel Behav. Soc. 2016, 3, 8-20. [CrossRef]

70. Hidrue, M.K.; Parsons, G.R.; Kempton, W.; Gardner, M.P. Willingness to pay for electric vehicles and their attributes. Resour. Energy Econ. 2011, 33, 686-705. [CrossRef]

71. Karlsson, S. What are the value and implications of two-car households for the electric car? Transp. Res. Part C Emerg. Technol. 2017, 81, 1-17. [CrossRef]

72. Moons, I.; De Pelsmacker, P. Emotions as determinants of electric car usage intention. J. Mark. Manag. 2012, 28, 195-237. [CrossRef]

73. Castaneda, M.G.; Martinez, C.; Marte, R.; Roxas, B. Explaining the environmentally sustainable consumer behavior: A social capital perspective. Soc. Responsib. J. 2015, 11, 658-676. [CrossRef]

74. White, L.V.; Sintov, N.D. You are what you drive: Environmentalist and social innovator symbolism drives electric vehicle adoption intentions. Transp. Res. Part A Policy Pract. 2017, 99, 94-113. [CrossRef]

75. Akehurst, G.; Afonso, C.; Martins Gonçalves, H. Re-examining green purchase behaviour and the green consumer profile. New evidences. Manag. Decis. 2012, 5, 972-988. [CrossRef]

76. Prothero, A.; Dobscha, S.; Freund, J.; Kilbourne, W.E.; Luchs, M.; Ozanne, L.K.; Thøgersen, J. Sustainable consumption: Opportunities for consumer research and public policy. J. Public Policy Mark. 2011, 30, 31-38. [CrossRef]

77. United Nations Environment Programme. Talk the Walk: Advancing Sustainable Lifestyles Through Marketing and Communications; Utopies: Paris France; Global Compact Office: New York, NY, USA; United Nations Environment Programme: Nairobi, Africa, 2015. 
78. Heffner, R.R.; Kurani, K.S.; Turrentine, T.S. Symbolism in California's early market for hybrid electric vehicles. Transp. Res. Part D Transp. Environ. 2007, 12, 396-413. [CrossRef]

79. Degirmenci, K.; Breitner, M.H. Consumer purchase intentions for electric vehicles. Is green more important than price and range? Transp. Res. Part D Transp. Environ. 2017, 51, 250-260. [CrossRef]

80. Van Rijnsoever, F.; Farla, J.; Dijst, M.J. Consumer car preferences and information search channels. Transp. Res. Part D Transp. Environ. 2009, 14, 334-342. [CrossRef]

81. Hultén, B. Sensory marketing: The multi-sensory brand-experience concept. Eur. Bus. Rev. 2011, 23, $256-273$. [CrossRef]

82. Krishna, A. Sensory Marketing: Research on the Sensuality of Products; Taylor and Francis Group: New York, NY, USA, 2011.

83. Streicher, M.C.; Estes, Z. Multisensory interaction in product choice: Grasping a product affects choice of other seen products. J. Consum. Psychol. 2016, 26, 558-565. [CrossRef]

84. Pine, B.J.; Pine, J.; Gilmore, J.H. The Experience Economy: Work Is Theatre E Every Business a Stage; Harvard Business Press: Harvard, MA, USA, 1999.

85. Homburg, C.; Koschate, N.; Hoyer, W.D. The interplay of cognition and affect in the formation of customer satisfaction: A dynamic perspective. Am. Mark. Assoc. 2005, 16, 222-301.

86. Klaus, P.; Maklan, S. The role of brands in a service-dominated world. J. Brand Manag. 2007, 15, 115-122. [CrossRef]

87. Hoch, S.J. Product experience is seductive. J. Consum. Res. 2002, 29, 448-454. [CrossRef]

88. Muhammad, M.; Artanti, Y. The impact of experiential marketing on word of mouth with customer satisfaction as a intervening variable. J. Din. Manaj. 2016, 7, 182-190. [CrossRef]

89. Freundt, T.C. Emotionlisierung von Marken: Inter-Industrieller Vergleich der Relevanz Emotioneler Markenimages Für das Konsumentenverhalten; Springer: Berlin, Germany, 2006; ISBN 383500395X.

90. Mooy, S.C.; Robben, H.S. Managing consumers' product evaluations through direct product experience. J. Prod. Brand Manag. 2002, 11, 432-446. [CrossRef]

91. Skippon, S.; Garwood, M. Responses to battery electric vehicles: UK consumer attitudes and attributions of symbolic meaning following direct experience to reduce psychological distance. Transp. Res. Part D Transp. Environ. 2011, 16, 525-531. [CrossRef]

92. Bühler, F.; Cocron, P.; Neumann, I.; Franke, T.; Krems, J.F. Is EV experience related to EV acceptance? Results from a German field study. Transp. Res. Part F Traffic Psychol. Behav. 2014, 25, 34-49. [CrossRef]

93. Rauh, N.; Franke, T.; Krems, J.F. Understanding the impact of electric vehicle driving experience on range anxiety. Hum. Factors 2015, 57, 177-187. [CrossRef]

94. Skippon, S.M.; Kinnear, N.; Lloyd, L.; Stannard, J. How experience of use influences mass-market drivers' willingness to consider a battery electric vehicle: A randomised controlled trial. Transp. Res. Part A Policy Pract. 2016, 92, 26-42. [CrossRef]

95. Schmalfuß, F.; Mühl, K.; Krems, J.F. Direct experience with battery electric vehicles (BEVs) matters when evaluating vehicle attributes, attitude and purchase intention. Transp. Res. Part F 2017, 46, 47-69. [CrossRef]

96. Albers, S.; Klapper, D.; Konradt, U.; Walter, A.; Wolf, J. Methodik der Empirischen Forschung; Springer: Wiesbaden, Germany, 2009.

97. Moss, S.; Prosser, H.; Costello, H.; Simpson, N.; Patel, P.; Rowe, S.; Turner, S.; Hatton, C. Reliability and validity of the PAS-ADD Checklist for detecting psychiatric disorders in adults with intellectual disability. J. Intellect. Disabil. Res. 1998, 42 Pt 2, 173-183. [CrossRef]

98. Razali, N.M.; Wah, Y.B. Power comparisons of shapiro-wilk, kolmogorov-smirnov, lilliefors and anderson-darling tests. J. Stat. Model. Anal. 2011, 2, 21-33.

99. Field, A. Discovering Statistics Using IBM SPSS Statistics, 4th ed.; SAGE Publications: Melbourne, Australia; Los Angeles, CA, USA; London, UK; New Delhi, India; Singapore; Washington, DC, USA, 2018.

100. Audi Media Center Audi e-tron schlägt am Flughafen München voll ein. 2019. Available online: https://www.audi-mediacenter.com/de/pressemitteilungen/audi-e-tron-schlaegt-am-flughafenmuenchen-voll-ein-11229 (accessed on 20 October 2019).

(C) 2019 by the authors. Licensee MDPI, Basel, Switzerland. This article is an open access article distributed under the terms and conditions of the Creative Commons Attribution (CC BY) license (http://creativecommons.org/licenses/by/4.0/). 